\title{
OPTIMIZATION OF MICRO GAS TURBINE BY ECONOMIC, EXERGY AND ENVIRONMENT ANALYSIS USING GENETIC, BEE COLONY AND SEARCHING ALGORITHMS
}

\author{
Amin Vafaei ${ }^{1}$, Mehdi A. Aliehyaei ${ }^{2, *}$
}

\begin{abstract}
In this paper it was dealt with optimization of micro gas turbine with natural gas fuel in four configurations of simple, with regenerator, combined heat and power (CHP) and CHP with regenerator. Target function included energy and exergy efficiencies and electricity cost by considering effects of environmental pollution. Optimization procedures were genetic, bee colony and searching algorithms. Results showed that optimum air fuel ratio calculated by searching method for micro gas turbine with above-mentioned cycles were 1.7, 1.3, 1.6 and 2.3 respectively. By applying Genetic algorithm, optimum air fuel ratios were 1.40, 1.21, 1.42 and 1.82 respectively. At these points, energy efficiency obtained as $29,34.4,39.4$ and $38.2 \%$, second law efficiency obtained as 61.4, 74.9, 85.4 and $57.2 \%$, electricity cost obtained as $0.102,0.086,0.075$ and 0.029 US $\$$ kWh respectively. By using bee colony algorithm, optimum air fuel ratios were $1.36,1.13,1.32$ and 1.61 respectively. At these points, energy efficiency are 28.2, 34.3, 40.5 and $35.6 \%$, second law efficiency are 60.9, 75.67, 81.80 and $56.65 \%$, electricity costs are $0.105,0.087,0.073$ and 0.03 US $\$ \mathrm{kWh}$ respectively. Among these methods, Genetic algorithm was selected as best method because of best answer in optimization.
\end{abstract}

Keywords: Micro Gas Turbine, Exergy, Air Pollution, Optimization, Genetic, Honey Bees, Ant Colony

\section{INTRODUCTION}

Today, energy and optimizing its consumption is one of the most important discussions in engineering. With attention to high cost of energy and decreasing fossil fuel sources, attentions are attracted to optimal usage of energy and controlling it's consumption through higher efficiency systems or new technologies. Studies in this regard, have been started long time ego in industrial countries and first steps are taken in developing countries [114]. Considering changes of structure of power generation, privatisation and also importance of environmental issues, technology of power generation is led to local generations. One of the most important methods is using micro turbine-generators. Today, more attention is paid to these generators, because of high efficiency and low volume beside lower environmental pollution. One of the common applications of micro gas turbines in local power generation is for residential sector with limited consumption demand [1-14]. According to statistics of power industry of Iran, provided by ministry of power, total generating electricity power of Iran at 2014 is 276 billion $k W / h$, which $31.7 \%$ of that is generated by steam plants, $26.5 \%$ is generated by gas turbines, $36.5 \%$ is generated by combined cycle power plants and only $5.3 \%$ is generated by hydropower, nuclear and renewable power plants. Also the main source of heat in Iran is natural gas. In summary, $94.7 \%$ of electricity power generation and $100 \%$ of energy for heating buildings is provided by fossil fuel sources specially natural gas in Iran. From the other side, most of applied fuels for power generation usually are not renewable and cause environmental pollution $[15,16]$. One of the methods used for optimization of power generation systems, is exergy analysis. In recent years, using micro gas turbines for synchronous generation of power and heat has attracted high attention. Many studies are conducted about modelling of gas turbines cycles, and also some studies are conducted about modelling of micro gas turbines cycles or any other dispersed power generation system [1-6, 9, 10, 12-14, 17-32]. Rajaei et al investigates micro gas turbine to meet need loads of residential building using bio gas as a fuel in rural area. They showed that digester tank and reservoir tank volumes are $67 \mathrm{~m} 3$ and $31.2 \mathrm{~m} 3$, respectively. The cost of electricity produced by this system is $0.446 \mathrm{US} \$ / \mathrm{kWh}$. For rural area in Iran, this system is not compatible with micro gas turbine and IC engine system use urban natural gas due to low price of natural gas in Iran, but it can be compatible by wind turbine, photovoltaic and hybrid system (wind turbine\& photovoltaic) systems.

This paper was recommended for publication in revised form by Regional Editor Omid Mahian 1Department of mechanical engineering, Dezful Branch, Islamic Azad University, Dezful, Iran

${ }^{2}$ Department of mechanical engineering, Pardis Branch, Islamic Azad University, Pardis new city, Iran

${ }^{\star} E$-mail address: aliehyaei@yahoo.com

Orcid id: 0000-0002-1002-4757, 0000-0002-4721-9427

Manuscript Received 26 October 2017, Accepted 14 January 2018 
Up to now, no research has been done about the optimization of one system with various optimization algorithms and comparison the results with each other. Also social cost of air pollution has not been considered in optimization in previous research. So in this study, in order to reach higher efficiency, optimization of these systems is performed. In this study, optimization is done for creation more economical providence and minimizing consumed fuel and environmental pollutants of micro turbine systems. Modern methods applicable in many optimization problems are based on artificial intelligence which are came from nature. In this research, Genetic algorithm, Bee colony and Searching method as three strong tools are used. Topic of the study is optimization of micro gas turbine by economic, exergy and environment analysis using Genetic, Bee colony and Searching algorithms. Innovations of this research are:

- Investigation of four modes of micro gas turbine including simple cycle, cycle of microturbine with regenerator, cycle of combined generation of heat and power and cycle of combined generation of heat and power accompanied by regenerator.

- Considering environmental effects for calculating cost of electricity which was called social cost of air pollution in this paper

- Using three methods of Search, Genetic and Bee colony algorithms for optimization of four abovementioned modes.

- Comparison the results of optimization with each other and selection the best optimization procedure

\section{Mathematical modelling}

In order to investigate microturbine system four models are considered:

- Simple cycle of microturbine.

- Microturbine cycle with regenerator.

- Microturbine combined cycle of generating heat and power.

- Microturbine combined cycle of generating heat and power with regenerator.

Figures 1 to 4 indicate four above modes. BC indicates Booster Compressor, CC indicates Combustion Chamber, RG indicates regeneration exchanger (or regenerator) and HX indicates combined heat and power generation exchanger.

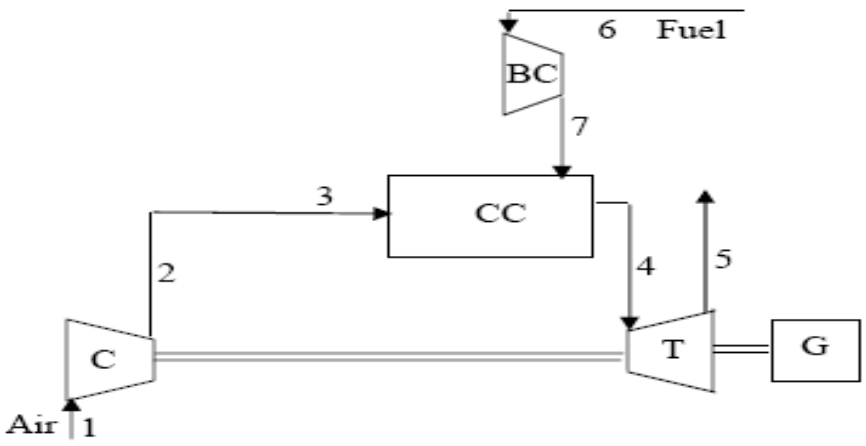

Figure 1. Simple cycle of micro turbine

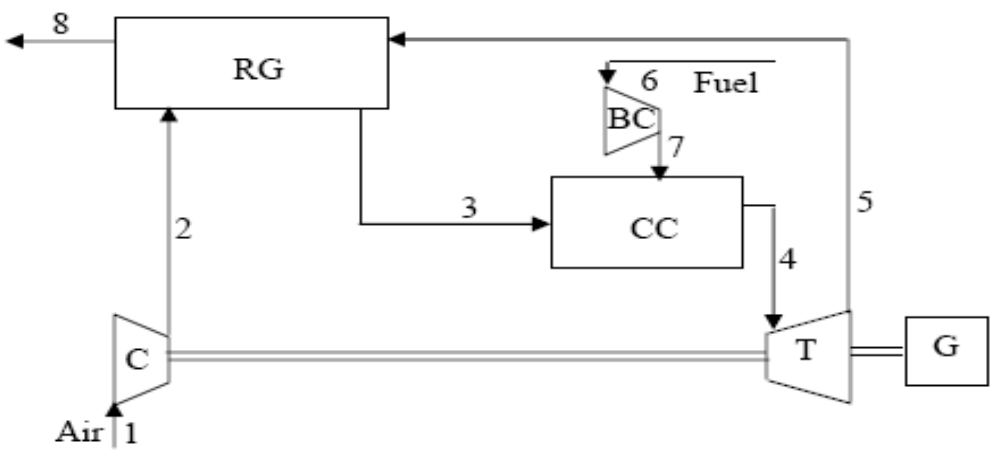

Figure 2. Micro turbine cycle with regenerator 


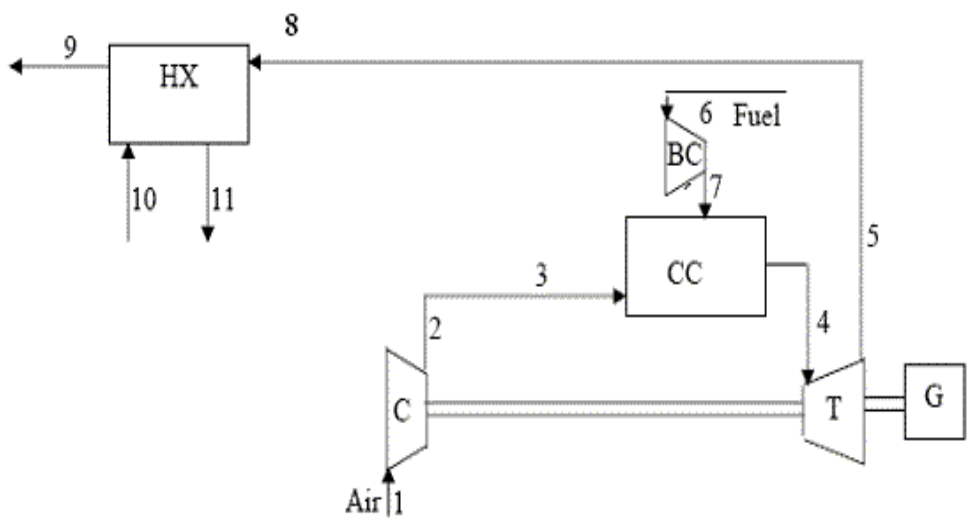

Figure 3. Micro turbine combined cycle of generating heat and power

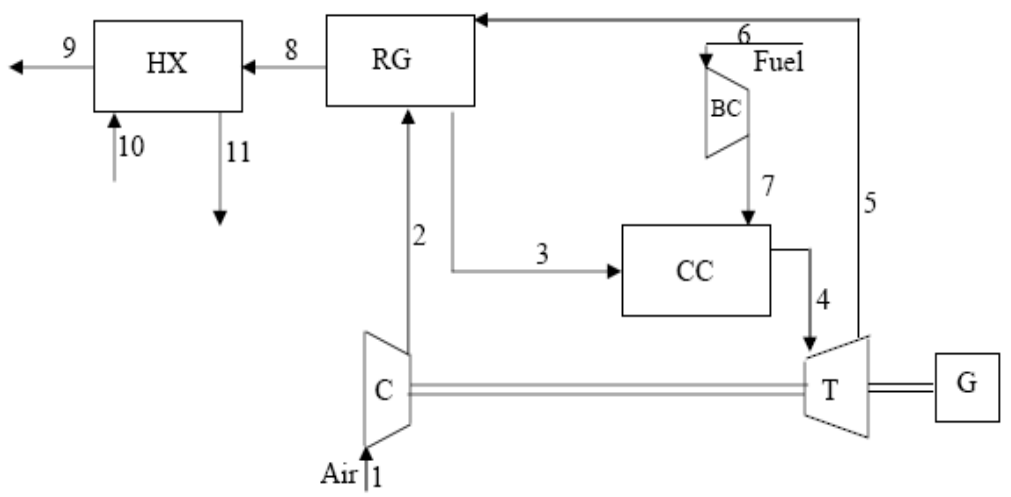

Figure 4. Micro turbine combined cycle of generating heat and power with regenerator

These systems work as such that air enters compressor after passing through filter and will be compressed. Compressed air enters a combustion chamber and gas burns in it. Output gases from combustion chamber enter turbine and exit after work generation. At regenerator mode, output gas from turbine enters regenerator exchanger and warms output air from compressor. At combined generation of heat and power, output gas from turbine enters combined generation of heat and power exchanger and exits after warming water. In general mode, micro gas turbine is a combination of a small gas turbine and a high speed generator. This generator is placed on a shaft which turbine and compressor are also placed on. Pressure ratio of micro turbine is between 4 to 6 and diameter of compressor and turbine is about $0.15 \mathrm{~m}$ for generating $35 \mathrm{~kW}$ under standard conditions. Generated electricity by high speed generator converts to alternative power with constant frequency [33]. For mathematical modelling the following assumption should be considered:

- System is steady state

- Physical and thermodynamic properties are constant

- System is control volume

- Pressure loss in connection pipes are about 3\%

- Heat loss is about $2 \%$

\section{Energy Analysis}

Outlet temperature and pressure and consumed work based on mass flow of compressor are calculated by using relations (1), (2) and (3) [33].

$$
\begin{gathered}
\left.T_{2}=T_{1} \mid 1+\left(r_{c}^{(k-1) / k}-1\right) / \eta_{c}\right\rfloor \\
\boldsymbol{P}_{2}=r_{c} \boldsymbol{P}_{1}
\end{gathered}
$$




$$
w_{c}=(k R / k-1) T_{1}\left[\left(r_{c}{ }^{(k-1) / k}-1\right) / \eta_{c}\right]
$$

where, $T_{1}$ : input temperature of air compressor $(K), T_{2}$ : output air temperature from compressor $(K), r_{c}$ : pressure ratio of compressor, $\mathrm{k}$ : ratio of specific heat of constant pressure to specific heat of constant volume, $\eta_{\mathrm{c}}$ : efficiency of compressor, $\mathrm{P}_{1}$ : input pressure of compressor $(\mathrm{kPa}), \mathrm{P}_{2}$ : output pressure of compressor $(\mathrm{kPa}), \mathrm{R}$ : gas constant $(\mathrm{kJ} / \mathrm{kg} \mathrm{K})$ and $\mathrm{w}_{\mathrm{c}}$ : work of mass flow unit of compressor $(\mathrm{kJ} / \mathrm{kg})$. Gas analysis is needed for investigating and designing combustion chamber which is according to table (1) [16].

Table 1. analysis of consumed gas in micro gas turbine [16]

\begin{tabular}{|c|c|c|c|c|c|c|}
\hline Component i & $\mathrm{CH}_{4}$ & $\mathrm{C}_{2} \mathrm{H}_{6}$ & $\mathrm{C}_{3} \mathrm{H}_{8}$ & $\mathrm{C}_{4} \mathrm{H}_{10}$ & $\mathrm{CO}_{2}$ & $\mathbf{N}_{2}$ \\
\hline $\mathrm{y}_{\mathrm{i}} \%$ molar & 81 & 7.9 & 4.2 & 4.7 & 1.2 & 1 \\
\hline $\mathrm{x}_{\mathrm{i}}, \%$ mass & 62.58 & 11.44 & 8.92 & 13.16 & 2.55 & 1.35 \\
\hline $\mathrm{M}_{\mathrm{i}}, \mathrm{kg} / \mathrm{kmole}$ & 16 & 30 & 44 & 58 & 44 & 28 \\
\hline $\mathrm{C}_{\mathrm{pi}}, \mathrm{kJ} / \mathrm{kg} \mathrm{K}$ & 2.25 & 1.76 & 1.67 & 1.64 & 0.84 & 1.04 \\
\hline $\begin{array}{l}\text { for the fuel } \\
\mathrm{M}_{\mathrm{f}}=\sum \mathrm{y}_{\mathrm{i}} \mathrm{M}_{\mathrm{i}} \\
\left(\mathrm{C}_{\mathrm{p}}\right)_{\mathrm{f}}=\sum \mathrm{x}_{\mathrm{i}} \mathrm{C} \\
\mathrm{R}_{\mathrm{f}}=\frac{\mathrm{R}_{\mathrm{u}}}{\mathrm{M}_{\mathrm{f}}}=0.4 \\
\mathrm{k}_{\mathrm{f}}=\left(\mathrm{C}_{\mathrm{\rho}}\right)_{\mathrm{f}} /\left(\mathrm{C}_{\mathrm{v}}\right. \\
\varepsilon_{c h}=\sum x_{i} \varepsilon_{c h, i}\end{array}$ & $\begin{array}{l}20.712 \\
=2.013 \\
1(\mathrm{~kJ} / \mathrm{kgK} \\
=1.249 \\
50285.12\end{array}$ & $\begin{array}{l}\text { noles }) \\
\mathrm{K}) \\
\mathrm{f}_{\mathrm{f}}=(\mathrm{C} \\
\mathrm{kgK})\end{array}$ & $\mathrm{f}_{\mathrm{f}}=1.6$ & $\mathrm{~kJ} / \mathrm{kg} \mathrm{K}$ & & \\
\hline
\end{tabular}

Combustion process is considered as follow:

$$
\begin{aligned}
& \left(0.81 C \mathrm{H}_{4}+0.079 \mathrm{C}_{2} \mathrm{H}_{6}+0.042 \mathrm{C}_{3} \mathrm{H}_{8}+0.047 \mathrm{C}_{4} \mathrm{H}_{10}+0.01 N_{2}+0.012 \mathrm{CO}_{2}\right)+2.412 r_{a}\left(O_{2}+3.76 N_{2}\right) \rightarrow \\
& a^{\prime} \mathrm{CO}_{2}+b^{\prime} \mathrm{H}_{2} \mathrm{O}+e^{\prime} \mathrm{O}_{2}+g^{\prime} \mathrm{CO}+d^{\prime} N_{2}+f^{\prime} \mathrm{NO} \\
& a=a^{\prime} / n^{\prime}, \quad b=b^{\prime} / n^{\prime}, \quad d=d^{\prime} / n^{\prime}, \quad e=e^{\prime} / n^{\prime}, \quad f=f^{\prime} / n^{\prime}, \quad g=g^{\prime} / n^{\prime}, \quad n^{\prime}=a^{\prime}+b^{\prime}+d^{\prime}+e^{\prime}+f^{\prime}+g^{\prime}
\end{aligned}
$$

where, $r_{a}$ is molar ratio of air to fuel. Considering following equations, we can investigate combustion process [33].

$$
\begin{aligned}
& 2 \mathrm{CO}_{2} \underset{\leftarrow}{\rightarrow} \mathrm{CO}+\mathrm{O} 2 \quad K_{\mathrm{CO}}=\frac{g^{2} e}{a^{2}}\left(\frac{P_{4}}{P_{3}}\right)^{2+1-2} \\
& \mathrm{~N}_{2}+\mathrm{O}_{2} \underset{\mathrm{L}}{\leftarrow} \mathrm{NO} \quad \mathrm{K}_{\mathrm{NO}}=\frac{\mathrm{f}^{2}}{\mathrm{de}}\left(\frac{\mathrm{P}_{4}}{\mathrm{P}_{3}}\right)^{2-1-1}
\end{aligned}
$$

Combustion process in combustion system is considered as following [33].

$$
\sum \dot{m}_{p}\left(h_{f}^{\circ}+\left(h-h_{o}\right)\right)_{p}=\eta_{c c} \sum \dot{m}_{r}\left(h_{f}^{\circ}+\left(h-h_{\circ}\right)\right)_{r}
$$

where, $\dot{\mathrm{m}}_{\mathrm{p}}$ : mass flow rate of productions $(\mathrm{kg} / \mathrm{s})$, $\dot{\mathrm{m}}_{\mathrm{r}}$ : mass flow rate of reactants $(\mathrm{kg} / \mathrm{s}), \eta_{\mathrm{cc}}$ : combustion efficiency, $\mathrm{h}$ : enthalpy $(\mathrm{kJ} / \mathrm{kg}), \mathrm{h}_{0}$ : enthalpy in reference temperature $(\mathrm{kJ} / \mathrm{kg})$, and $\mathrm{h}_{\mathrm{f}}^{\mathrm{f}}$ : enthalpy of formation $(\mathrm{kJ} / \mathrm{kg})$. Pressure in combustion chamber is also computed as follow. 


$$
P_{4}=P_{3} \frac{n_{3}}{n_{4}} \frac{T_{3}}{T_{4}}
$$

where, $\mathrm{n}_{3}$ : number of moles before entering combustion chamber, $\mathrm{T}_{3}$ : number temperature before entering combustion chamber $(\mathrm{K}), \mathrm{P}_{4}$ : pressure of combustion chamber $(\mathrm{kPa}), \mathrm{n}_{4}$ : number of moles in combustion chamber and $\mathrm{T}_{4}$ : temperature of combustion chamber $(\mathrm{K})$. Output temperature and pressure and output work of turbine in mass unit are also calculated by following equations:

$$
\begin{gathered}
T_{5}=T_{4}\left(1-\eta_{t}\left(1-\frac{1}{r_{t}^{\frac{k-1}{k}}}\right)\right) \\
P_{5}=\frac{P_{4}}{r_{t}} \\
w_{t}=\frac{k R T_{4}}{k-1}\left[1-\left(\frac{P_{5}}{P_{4}}\right)^{\frac{k-1}{k}}\right] \eta_{t}
\end{gathered}
$$

where, $\mathrm{T}_{5}$ : output temperature of micro gas turbine $(\mathrm{K}), \mathrm{r}_{\mathrm{t}}$ : pressure ratio of micro gas turbine, $\mathrm{\eta}_{\mathrm{t}}$ : efficiency of micro gas turbine and $\mathrm{P}_{5}$ : output pressure of gas turbine $(\mathrm{kPa})$. Net generating work of micro gas turbine is also calculated by following equation.

$$
\begin{gathered}
\dot{W}_{\text {net }}=\left(\dot{m}_{a}+\dot{m}_{f}\right) w_{t}-\dot{m}_{a} w_{c}-\dot{m}_{f} w_{b c} \\
=\dot{m}_{f}\left[\left(\frac{\dot{m}_{a}}{\dot{m}_{f}}+1\right) w_{t}-\frac{\dot{m}_{a}}{\dot{m}_{f}} w_{c}-w_{b c}\right]
\end{gathered}
$$

where, $\dot{\mathrm{W}}_{\text {net }}$ : net generating work of micro gas turbine $(\mathrm{Kw})$ and $\mathrm{W}_{\mathrm{bc}}$ : consumed work of fuel compressor based on mass flow unit $(\mathrm{Kj} / \mathrm{kg})$, $\dot{\mathrm{m}}_{\mathrm{a}}$ : mass flow of air $(\mathrm{kg} / \mathrm{s})$ and $\dot{\mathrm{m}}_{\mathrm{f}}$ : mass flow of fuel $(\mathrm{kg} / \mathrm{s})$. Schematic design of heat exchanger of combined generation of heat and power is shown in figureure 5 and for design $\in-N T U$ method is used [34].

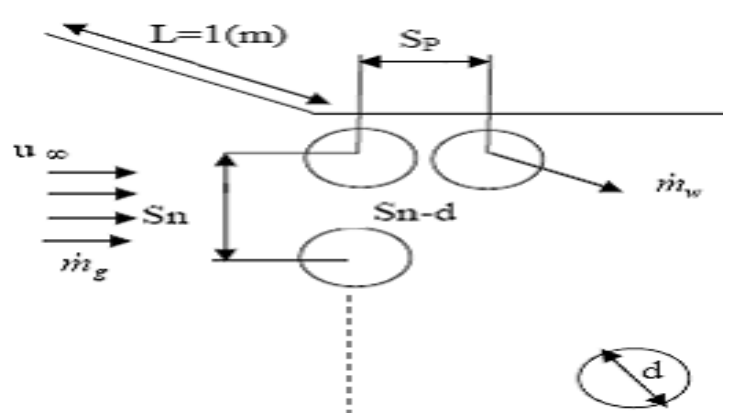

Figure 5. Heat exchanger of CHP [33]

At first step values of $\mathrm{C}_{\min }$ and $\mathrm{C}_{\max }$ can be calculated by following equations [34].

$$
C_{g}=\dot{m}_{g} C_{p_{g}}
$$




$$
C_{w}=\dot{m}_{w} C_{p_{w}}
$$

where, $\mathrm{C}_{\mathrm{g}}$ : input energy of hot gas in temperature unit $(\mathrm{Kw} / \mathrm{K}), \mathrm{C}_{\mathrm{w}}$ : input energy of water in temperature unit $(\mathrm{Kw} / \mathrm{K}), \mathrm{C}_{\mathrm{Pg}}$ : specific heat of hot gas $(\mathrm{Kj} / \mathrm{kgK}), \mathrm{C}_{\mathrm{Pw}}$ : specific heat of water $(\mathrm{Kj} / \mathrm{kgK})$, mg: mass flow of hot gas $(\mathrm{kg} / \mathrm{s})$ and $\dot{\mathrm{m}}_{\mathrm{w}}$ : mass flow of water $(\mathrm{kg} / \mathrm{s})$. Values of $\mathrm{C}_{\min }$ and $\mathrm{C}_{\max }$ are computed based on following equations [34].

$$
\begin{gathered}
C_{\text {min }}=\min \left\{C_{g}, C_{w}\right\} \\
C_{\text {max }}=\max \left\{C_{g}, C_{w}\right\}
\end{gathered}
$$

Value of Nu number for water is obtained from equation (17), this equation is for calculating Nusselt number for turbulent flow [34].

$$
N u_{w}=0.23 \operatorname{Re}_{w}^{0.8} \operatorname{Pr}_{w}^{0.4}
$$

where, $\mathrm{Nu}_{\mathrm{w}}$ : Nusselt number of water, $\mathrm{Re}_{\mathrm{w}}$ : Reynolds number of water and $\operatorname{Pr}_{\mathrm{w}}$ : Prantel number of water. Reynolds number is defined as follow, this equation for calculation Reynolds number of tubular duct [34].

$$
\operatorname{Re}_{w}=\frac{4 \dot{m}_{w}}{\pi d n \mu_{w}}
$$

where, d: diameter of the pipe (m), n: number of pipe branch and $\mu_{\mathrm{w}}$ : viscosity coefficient of water $(\mathrm{N} . \mathrm{S} / \mathrm{m})$. Convection heat transfer coefficient in water is as follow [34].

$$
h_{w}=\frac{k}{d} N u_{w}
$$

where, $\mathrm{h}_{\mathrm{w}}$ : convection heat transfer coefficient of water $\left(\mathrm{W} / \mathrm{m}^{2} \mathrm{~K}\right)$. Nusselt number for hot gas flow with condition $1 \leq \operatorname{Pr} \leq 60$ and $1000 \leq \operatorname{Re} \leq 5 * 10^{5}$ is also equals to [34]

$$
N u_{g}=\frac{h_{g} d}{k}=C \operatorname{Re}_{g \cdot \max } \operatorname{Pr}_{g}{ }^{n}
$$

where, Nug: 122usselt number of gas, $\mathrm{Re}_{\mathrm{g} \text {.max}}$ : maximum Reynolds number of gas, $\operatorname{Prg}_{\mathrm{g}}$ prantel number of gas, $\mathrm{h}_{\mathrm{g}}$ : heat transfer coefficient of gas $\left(\mathrm{W} / \mathrm{m}^{2} \mathrm{~K}\right)$ and $\mathrm{C}$ and $\mathrm{n}$ : constant reference coefficients [33]. Reg.max number is calculated as follow [34].

$$
\operatorname{Re}_{g, \max }=\frac{\rho u_{\max } d}{\mu}
$$

where, $\rho:$ density $\left(\mathrm{kg} / \mathrm{m}^{3}\right)$, and $u_{\max }$ : maximum speed of the gas $(\mathrm{m} / \mathrm{s})$. $\mathrm{u}_{\max }$ is also defined as follow [34].

$$
\frac{u_{\max }}{u_{\infty}}=\frac{S_{n}}{S_{n}-d}
$$

where, $\mathrm{u}_{\infty}$ : free flow speed of the gas $(\mathrm{m} / \mathrm{s})$ and $\mathrm{S}_{\mathrm{n}}$ : lateral step which is assumed 1.5 times more than diameter (m). Free flow speed of fluid can be computed as follow [34]. 


$$
u_{\infty}=\frac{\dot{m}_{g}}{2 \rho L S_{n}}
$$

where, L: length of exchanger (m). Conduction coefficient is expressed by relation (24) [34].

$$
u_{t}=\frac{1}{\frac{1}{h_{g}}+\frac{1}{h_{w}}}
$$

where, $\mathrm{u}_{\mathrm{t}}$ : total conduction coefficient $\left(\mathrm{W} / \mathrm{m}^{2} \mathrm{~K}\right)$. Number of thermal units is also obtained by following relation [34].

$$
N T U=\frac{u_{t} A}{C_{\min }}
$$

where, NTU: number of thermal units and A: effective interface of heat transfer $\left(\mathrm{m}^{2}\right)$. With attention to exchanger array, effectiveness of it is calculated from following equation [34].

$$
\in=\frac{T_{10}-T_{11}}{T_{8}-T_{9}}=2\left\{1+C r+\left(1+C r^{2}\right)^{\frac{1}{2}} \frac{1+\exp \left(-N T U\left(1+C r^{2}\right)\right)^{\frac{1}{2}}}{1-\exp \left(-N T U\left(1+C r^{2}\right)\right)^{\frac{1}{2}}}\right\}^{-1}
$$

where, $T_{8}$ : input temperature of hot gas in exchanger $(K), T_{9}$ : output temperature of hot gas in exchanger $(K), T_{10}$ : input temperature of water in exchanger $(K), T_{11}$ : output temperature of water in exchanger $(K), \in$ : effectiveness of exchanger and $C_{r}$ : ratio of water energy rate to hot gas energy rate. $C_{r}$ is as follow [34].

$$
C_{r}=\frac{\dot{m}_{w} C_{p w}}{\dot{m}_{g} C_{p_{g}}}
$$

With attention to relations (17) to (23), we can calculate output temperature of water and output temperature of the gas in CHP exchanger. For designing regeneration exchanger, $\in-N T U$ is used as before [34]. Figure 6 shows regeneration exchanger.

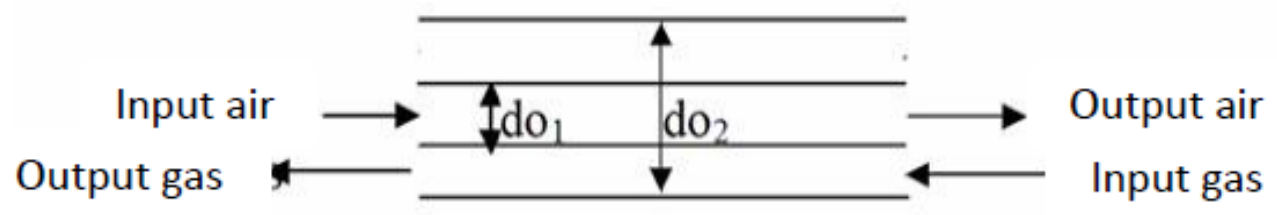

Figure 6. A scheme of regeneration exchanger

Effectiveness of exchanger is defined based on following equation [34].

$$
\in=\frac{N T U}{N T U+1}
$$

Efficiency of first law of micro turbine in simple and CHP forms is calculated by following equations.

$$
\eta_{I}=\frac{\dot{W}_{\text {net }}}{\dot{m}_{f} L H V}
$$




$$
\eta_{I}=\frac{\dot{W}_{n e t}+\eta_{\text {Carnot }} \dot{m}_{w} C_{p w}\left(T_{11}-T_{10}\right)}{\dot{m}_{f} L H V}
$$

where, $\eta_{1}$ : efficiency of first law of thermodynamic, $\eta_{\text {camot }}$ : efficiency of Carnot cycle and LHV: lower heating value of fuel $(\mathrm{Kj} / \mathrm{kg})$.

\section{Exergy Analysis}

Total exergy of system is sum of chemical and physical exergies, their relations are as follow [35].

$$
\begin{gathered}
e_{p h}=C_{p} T_{o}\left[\frac{T}{T_{o}}-1-\ln \left(\frac{T}{T_{o}}\right)\right]+R T_{o} \ln \frac{P}{P_{o}} \\
e_{c h}=\sum_{i=1}^{n} x_{i} e_{c h, i}+R T_{o} \sum_{i=1}^{n} x_{i} \ln \left(x_{i}\right) \\
e_{t}=e_{p h}+e_{c h}
\end{gathered}
$$

where, $e_{t}$ : total exergy $(\mathrm{kJ} / \mathrm{kg})$, $\mathrm{e}_{\mathrm{ph}}$ : physical exergy $(\mathrm{kJ} / \mathrm{kg})$, $\mathrm{e}_{\mathrm{ch}}$ : chemical exergy $(\mathrm{kJ} / \mathrm{kg})$, $\mathrm{e}_{\mathrm{ch}, \mathrm{i}}$ : chemical exergy of each component of the fuel $(\mathrm{kJ} / \mathrm{kg}), \mathrm{T}_{0}$ : reference temperature equals to $298.15(\mathrm{k})$ and $\mathrm{P}_{0}$ : reference pressure equals to $101.3(\mathrm{kPa})$.

Total entropy generation rate of the system in simple and CHP forms are as following [35].

$$
\begin{gathered}
\dot{S}_{\text {gen }}=\frac{1}{T_{o}}\left[\sum_{\text {in }} \dot{m} e_{t}-\sum_{\text {out }} \dot{m} e_{t}-\dot{W}_{\text {net }}\right] \\
\dot{S}_{\text {gen }}=\frac{1}{T_{o}}\left[\sum_{\text {in }} \dot{m} e_{t}-\sum_{\text {out }} \dot{m} e_{t}-\dot{W}_{\text {net }}-\eta_{\text {Carnot }} \dot{m}_{w} C_{p w}\left(T_{11}-T_{10}\right)\right]
\end{gathered}
$$

where, $\dot{\mathrm{S}}_{\text {gen: }}$ rate of entropy generation $(\mathrm{kW} / \mathrm{K})$. Second law of thermodynamic efficiency for simple and CHP mode is also computed as follow respectively [35].

$$
\begin{gathered}
\eta_{I I}=\frac{\dot{W}_{\text {net }}}{\sum_{\text {in }} \dot{m} e_{t}-\sum_{\text {out }} \dot{m} e_{t}} \\
\eta_{I I}=\frac{\dot{W}_{\text {net }}+\dot{m}_{w} C_{p w}\left(T_{11}-T_{10}\right)}{\sum_{\text {in }} \dot{m} e_{t}-\sum_{\text {out }} \dot{m} e_{t}}
\end{gathered}
$$

where, $\eta_{\text {II: }}$ second law of thermodynamic efficiency. With attention to obtained relations, efficiency of second law and generating entropy rate of the system are function of below parameters.

$$
\eta_{I I} \text { and } \dot{S}_{g e n}=f\left(r_{c}, r_{b}, r_{t}, T_{1}, \dot{m}_{a}, \dot{m}_{f}, r_{a}, \dot{W}_{\text {net }}\right)
$$


Considering that $\mathrm{r}_{\mathrm{b}}, \mathrm{r}_{\mathrm{c}}$ and $\mathrm{r}_{\mathrm{t}}$ are always constant in the micro turbine and changing them requires changing total array or model of turbine, booster compressor and compressor, and also since changing environmental conditions are out of ability of designer, so, input temperature and pressure are considered in ISO conditions $\left(101.3 \mathrm{kPa}\right.$ and $\left.25^{\circ} \mathrm{C}\right)$. Furthermore, keeping amount of fuel consumption constant, relation (38) is simplified as follow.

$$
\eta_{I I}, \dot{S}_{g e n}=f\left(r_{a}\right)
$$

\section{Economic and Environmental Analysis}

Cost of generated electricity of microturbine is calculated as follow.

$$
\mathrm{C}_{\mathrm{E}}=\mathrm{C}_{1}+\mathrm{C}_{\mathrm{O}}+\mathrm{C}_{\mathrm{F}}+\mathrm{C}_{\mathrm{A}}
$$

where, $C_{E}$ : cost (US\$/kWh), $C_{1}$ : initial installation cost (US\$ $\left./ \mathrm{kWh}\right), \mathrm{C}_{\mathrm{O}}$ : maintenance cost (US\$/kWh), $\mathrm{C}_{\mathrm{F}}$; cost of fuel (US\$/kWh) and $C_{A}$ : social cost relating air pollutant (US $\left.\$ / k W h\right)$. Electricity cost relating initial installation is calculated from following equation[36, 37] .

$$
C_{I}=\frac{C I}{E E_{a v e} n_{d}}
$$

here, C: cost of initial installation (US\$), I: profit of initial cost, $\mathrm{EE}_{\text {ave: }}$ average of consumed electricity (kWh/day) and $\mathrm{n}_{\mathrm{d}}$ : number of days in a month. Initial cost profit is calculated as follow [36, 37].

$$
I=\frac{1}{12} \frac{i(1+i)^{L}}{(1+i)^{L}-1}
$$

where, L: life time of micro gas turbine (year) and i: profit rate. Cost related to fuel cost is calculated as follow $[36,37]$.

$$
C_{F}=\frac{\text { Fuel cost }\left(\frac{U S \$}{k W h}\right)}{\eta_{I}}
$$

Cost related to social costs of air pollutants is also calculated as follow[36, 37].

$$
C_{A}=\left[\dot{m}_{\mathrm{NO}}\left(C_{A, \mathrm{NO}}\right)+\dot{m}_{\mathrm{CO}}\left(C_{A, \mathrm{CO}}\right)+\dot{m}_{\mathrm{CO}_{2}}\left(C_{A, C O_{2}}\right)\right] \frac{1}{3600 \mathrm{~W}}
$$

where, $\dot{\mathrm{m}}_{\mathrm{CO} 2}$, $\dot{\mathrm{m}}_{\mathrm{CO}}$ and $\dot{\mathrm{m}}_{\mathrm{NO}}$ are mass flow of carbon dioxide, carbon monoxide and nitrogen monoxide respectively $(\mathrm{kg} / \mathrm{s})$ and $\mathrm{C}_{\mathrm{A}, \mathrm{CO} 2}, \mathrm{C}_{\mathrm{A}, \mathrm{CO}}$ and $\mathrm{C}_{\mathrm{A}, \mathrm{NO}}$ are social costs of pollutants carbon dioxide, carbon monoxide and nitrogen monoxide respectively (US\$/kg). Cost of generated power of a micro gas turbine in CHP mode is as follow.

$$
\left.C_{E}=C_{I} \text { - } C_{\text {Iassumed boiler }}+C_{0}-C_{0}\right)_{\text {assumed boiler }}+C_{F}-C_{\text {Fassumed boiler }}+C_{A} \text { - } C_{\text {Aassumed boiler }}
$$

In CHP mode in order to calculate power cost based on equation (45), initial and maintenance costs and social costs of environmental pollutants of an assumed boiler which generates amount of energy that is regenerated from microturbine, are deduced from cost of generated electricity by microturbine.

In economical, exergy and environmental mode, equation (40) is used with this difference that $\mathrm{C}_{\mathrm{EX}}$ is used instead of $C_{F}$, which is electricity cost related to exergy cost. Electricity cost related to exergy cost can be calculated as follow. 


$$
C_{E X}=\frac{\operatorname{Exergycos} t\left(\frac{\$}{k W h}\right)}{\eta_{I I}}
$$

Exergy cost can be calculated by using following equation.

$$
\text { Exergy } \cos t\left(\frac{\$}{k W h}\right)=\frac{\text { Fuel } \cos t\left(\frac{\$}{k W h}\right) L H V}{\varepsilon_{c h}}
$$

\section{Optimization Methods}

Many of optimization problems in engineering are naturally very complex and difficult to solve by traditional optimization methods like mathematical planning and the likes. Combinational optimization is search for finding optimal points of functions with discrete variables. Today, many of combinational optimization problems including NP-Hard can be solved approximately by existing computers. Present solutions for solving such problems include using approximate or innovative algorithms. These algorithms don't guarantee that obtained answer is optimal and only through passing a lot of time we can obtain an approximately exact answer. In fact, accuracy of the answer changes depending on spent time [38]. In this study, three algorithms; Searching method, Bee colony and Genetic algorithm are applied for optimization.

Searching method is a trial and error which considers a point and compares value of objective function at this point with other points. If value of objective function is maximum at this point, this point is considered as optimum point, otherwise, this point is no more optimum. Flowchart of this algorithm is shown in figure 7 [38].

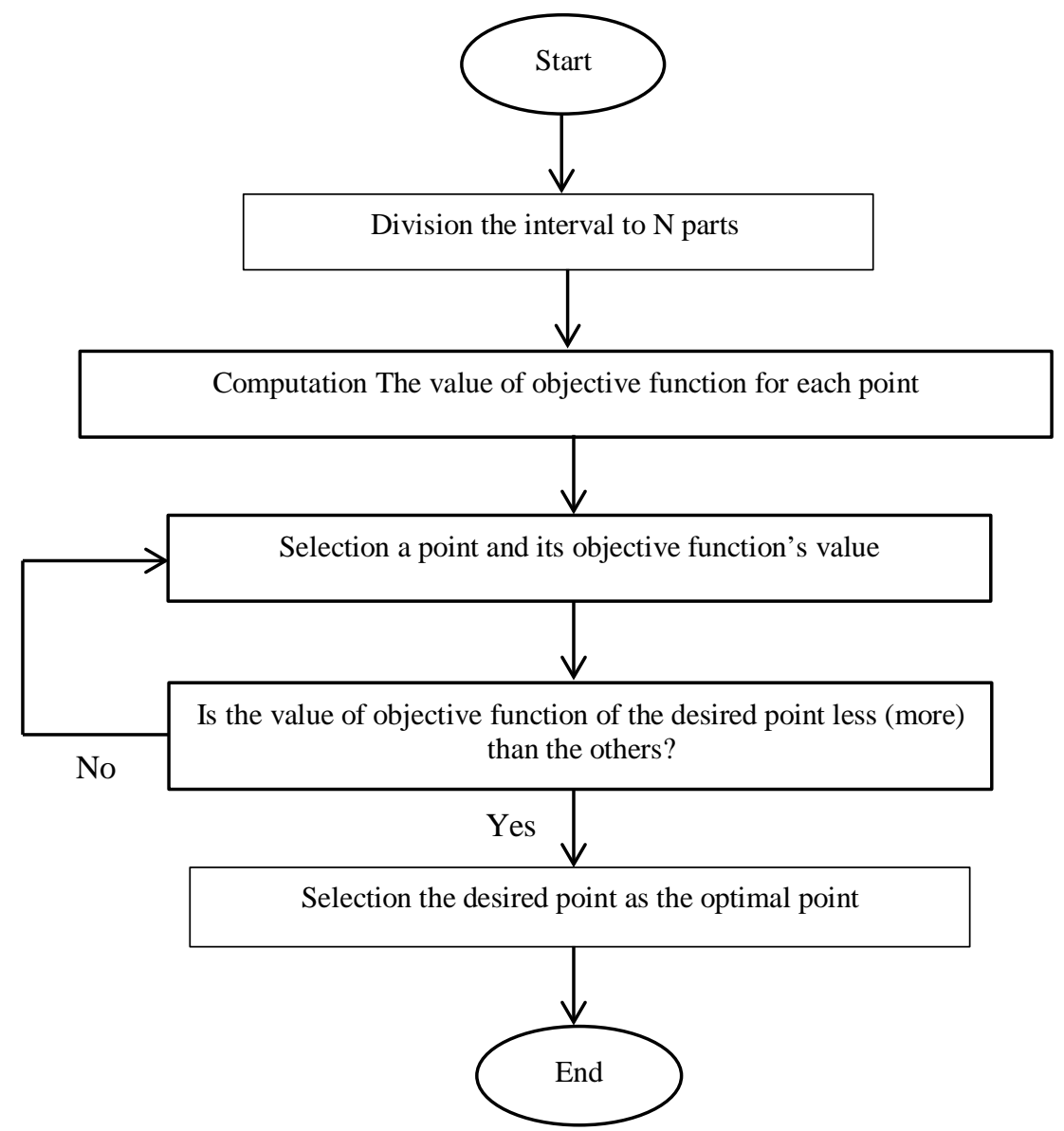

Figure 7. Flowchart of Searching method 
Genetic algorithm is one of the intelligent search methods which selects a population randomly from a sample environment and forms a generation of chromosomes. Then, by using selection operator, some of chromosomes with better characteristics than others are selected and by applying coupling and recombination operators, chromosomes are combined as parents and from every two parents at least two children are generated. As such a new generation with better characteristics is generated. In order to prevent premature convergence and losing better answers, mutation operator generates chromosomes with new characteristics which are not available in first generation. Superiority of chromosomes to each other, is determined by a fitness function which is assigned to chromosomes. Flowchart of this algorithm is shown in figure 8 [39].

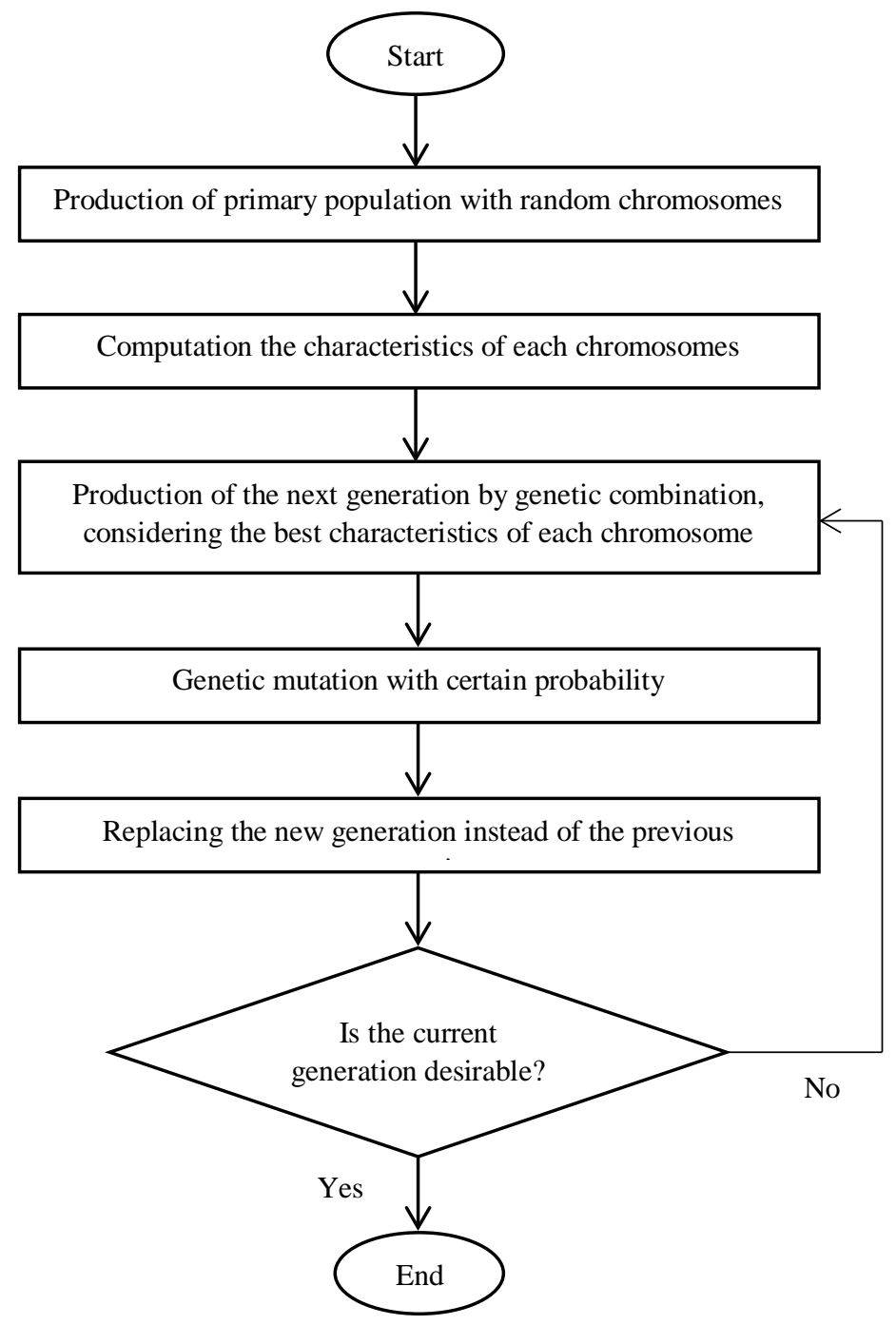

Figure 8. Genetic algorithm flowchart

Bee colony algorithm simulates heuristics behaviour of bee colony for optimization problems without constraint. In a real bee colony, there are functions which are done by expert bees. These expert bees try to maximize amount of stored nectar in hive by work division and self-organization. Minimization model of selecting food search by intelligent bee groups in a bee colony (ABC) involves three types of bee: employee bee, onlooker bee and scout bee. Half of colony involves employee bees and the other half involves onlooker bees. Employee bees are responsible for exploiting nectar sources which have been discovered already. They also share information about quality of location of food sources with other awaiting bees (onlooker bees). Onlooker bees stay in hive and decide on exploiting a food source based on shared information by employee bees. Scout bees search for a new food source randomly based on random or an internal motivation. Flowchart of this algorithm is shown in figure 9 [40]. 


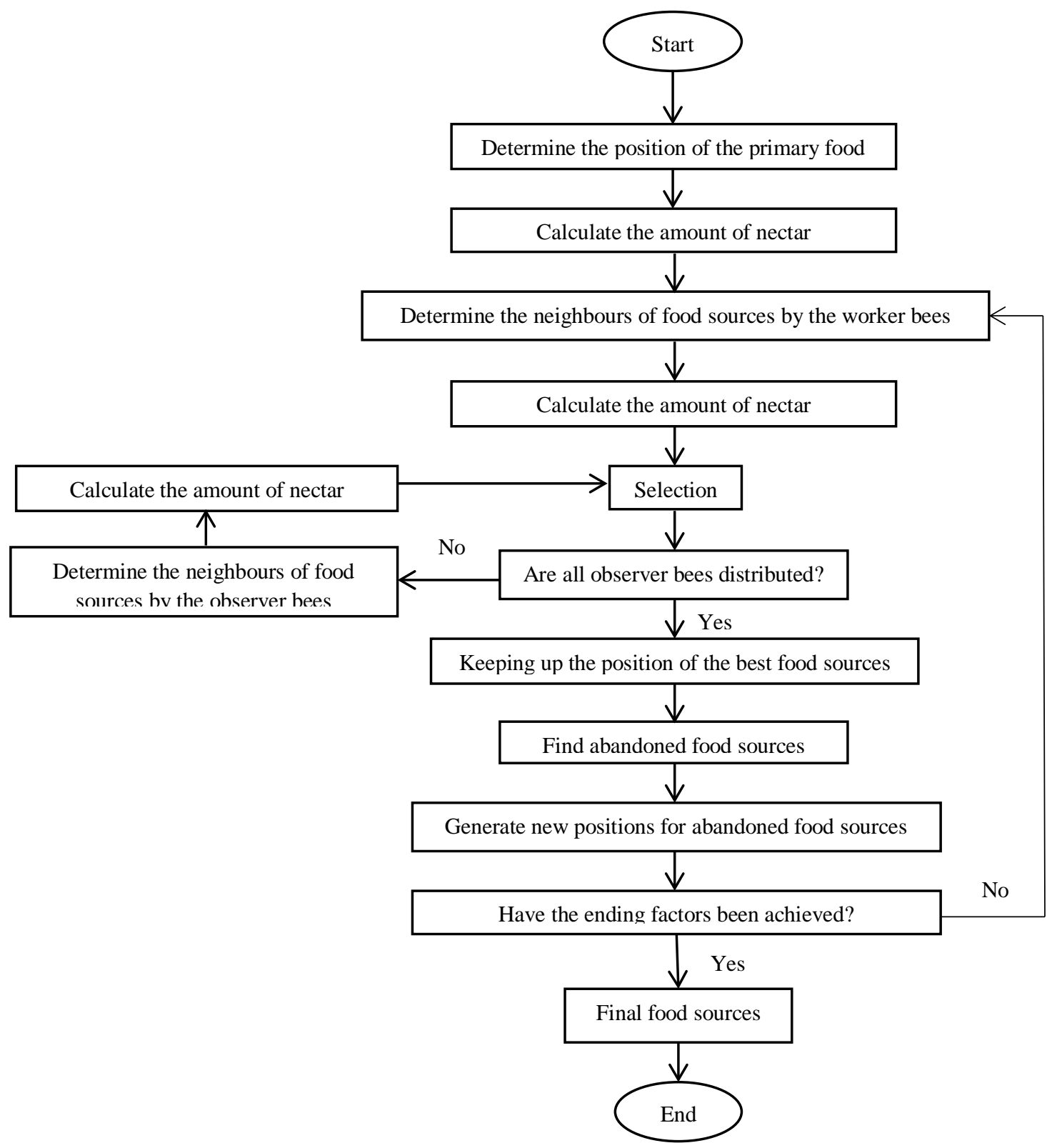

Figure 9. Bee Colony algorithm flowchart

\section{RESULTS AND DISCUSSION}

In this paper in order to investigate various operational modes of micro gas turbine, at first each of four above-mentioned modes are simulated in MATLAB by written codes. Then using written code, results of thermodynamic analysis are provided and finally by using searching method, Genetic algorithm and Bee Colony algorithm, optimum point for performance of cycle will be obtained.

In this paper design parameters are considered as follow:

Air characteristics: $k=1.4, R=0.287(\mathrm{~kJ} / \mathrm{kgK}), C_{p}=1.004(\mathrm{~kJ} / \mathrm{kgK}), T_{1}=298.15(\mathrm{~K})$, $P_{1}=100(\mathrm{kPa})$,

Air compressor characteristics: $\eta_{c}=85 \%, r_{c}=6.5$

Fuel characteristics: $\quad R_{f}=0.401(\mathrm{~kJ} / \mathrm{kgK}), \quad C_{p f}=2.013(\mathrm{~kJ} / \mathrm{kgK}), \quad k_{f}=1.249$, $T_{6}=15{ }^{\circ} \mathrm{C}, P_{6}=100 \mathrm{kPa}, \dot{\mathrm{m}}_{\mathrm{f}}=1.93 叉 10^{3}(\mathrm{~kg} / \mathrm{s})$

Fuel compressor characteristics: $\eta_{\mathrm{bc}}=85 \%, r_{b c}=6.5$,

Gas turbine characteristics: $\eta_{\mathrm{t}}=85 \%, r_{\mathrm{t}}=6.5$, 
Characteristics of water in CHP exchanger: $C_{p w}=4.18(\mathrm{~kJ} / \mathrm{kgK}), k=28.036(\mathrm{~W} / \mathrm{mK}), L=1(\mathrm{~m})$, $\dot{m}_{W}=0.5(\mathrm{~kg} / \mathrm{sec})$,

Characteristics of CHP exchanger: $n=25, d=0.01(\mathrm{~m}), S_{n}=1.25 d(\mathrm{~m}), S_{p}=1.25 d(\mathrm{~m})$

Characteristics of regeneration exchanger: $d o_{1}=0.04 \mathrm{~m}, d o_{2}=0.08 \mathrm{~m}, L=0.08(\mathrm{~m})$,

And other parameters are the same as referred in equations and simulation of micro gas turbine.

In order to validate written code in this paper, obtained results are compared with results of Mozaffari and Ehyaei [17]. It is worth-noting that in this reference simple mode of micro gas turbine cycle is investigated (shown cycle in figure 1). Obtained results of this comparison are shown in figure $10-12$ for energy efficiency, exergy efficiency and cost function respectively by considering pollution according to molar ratio of air to fuel. As observed, written code gives changes with a good accuracy and variation in present work is similar to reported variation by Mozaffari et al.

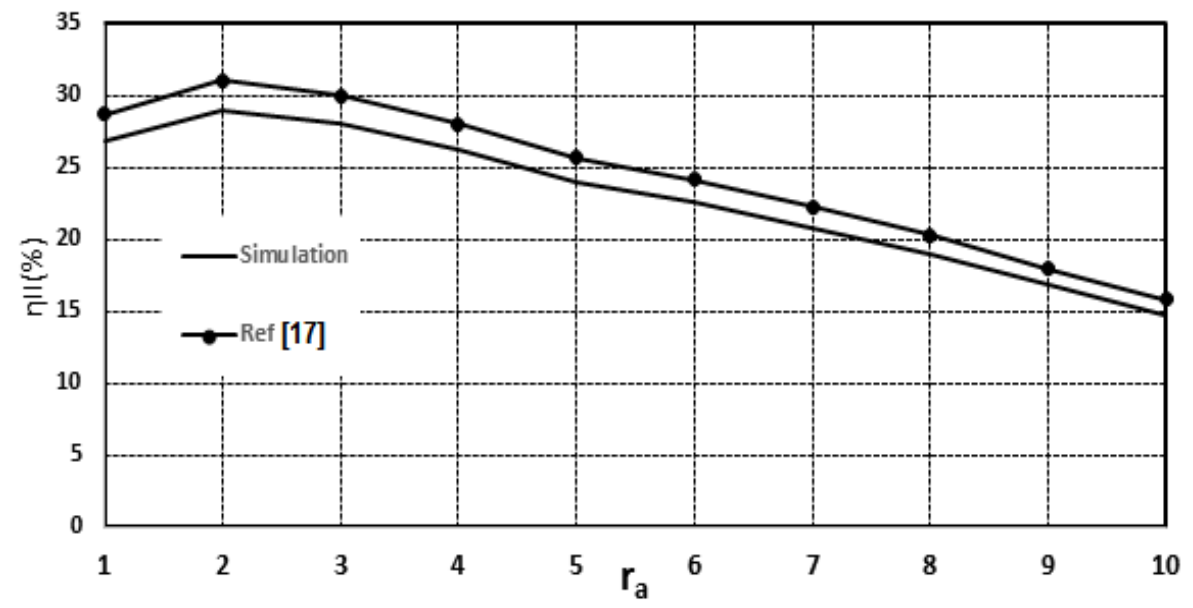

Figure 10. Comparison of energy efficiency of simple cycle of micro turbine with reference [17]

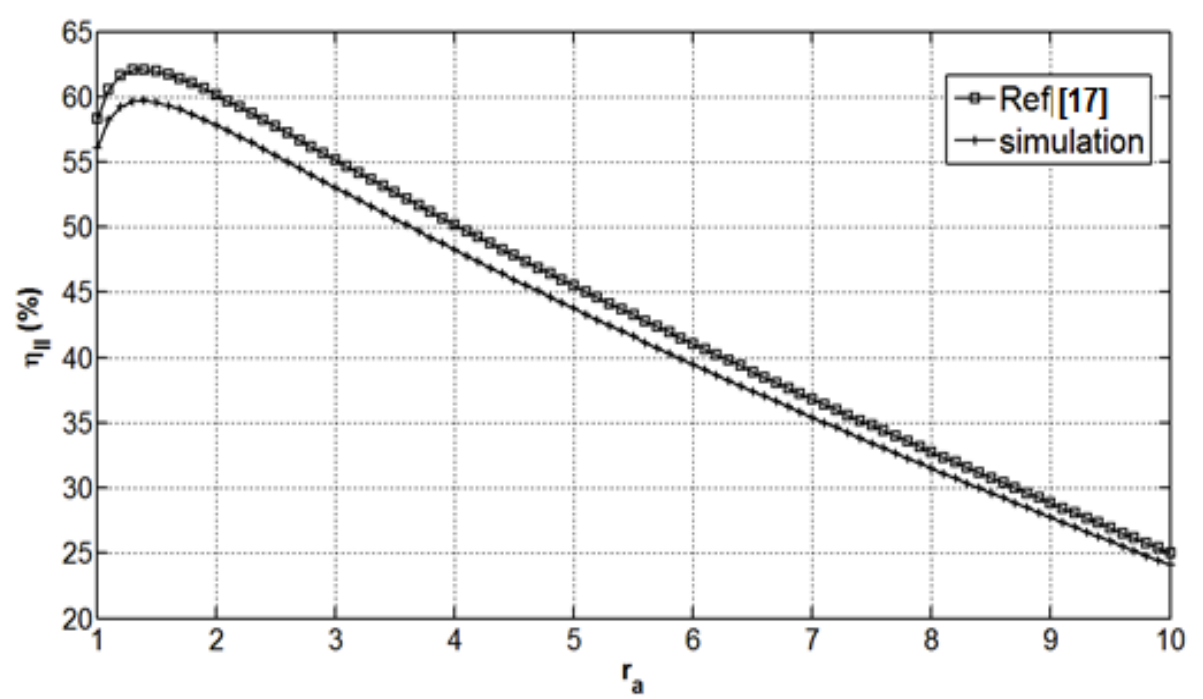

Figure 11. Comparison of exergy efficiency of simple cycle of micro turbine with reference [17] 


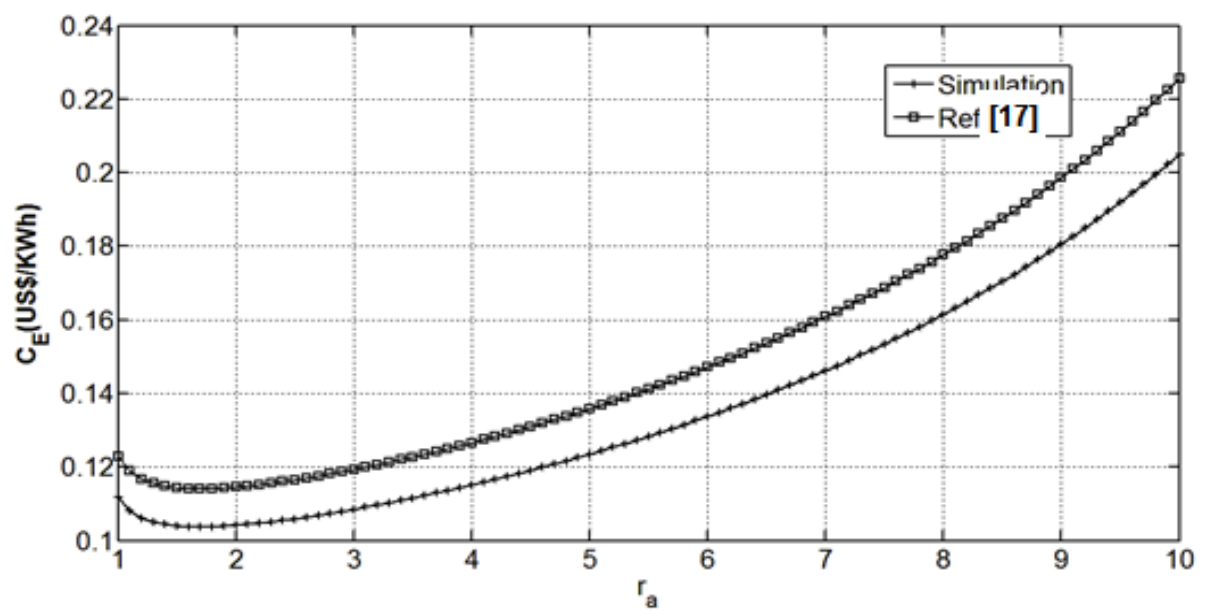

Figure 12. Comparison of cost function of simple cycle of micro turbine with reference [17]

\section{Simulation results for various modes}

Values of various parameters of simple cycle for ratio of air to fuel 5 are compared with reference [17]in table 2, and results show that results of this simulation have a good accuracy.

Table 2. Comparing parameters of simple cycle of this paper with reference [17] for $\mathrm{r}_{\mathrm{a}}=5$

\begin{tabular}{|c|c|c|c|}
\hline Parameter & Simulation & Ref[17] & Error(\%) \\
\hline $\mathrm{T}_{1}(\mathrm{~K})$ & 298.2 & 298.2 & 0 \\
\hline $\mathrm{T}_{2}(\mathrm{~K})$ & 546.18 & 532.2 & 2.6 \\
\hline $\mathrm{T}_{3}(\mathrm{~K})$ & 546.18 & 532.2 & 2.6 \\
\hline $\mathrm{T}_{4}(\mathrm{~K})$ & 1129.7 & 1148.3 & 1.6 \\
\hline $\mathrm{T}_{5}(\mathrm{~K})$ & 731.94 & 744 & 1.6 \\
\hline $\mathrm{W}_{\text {net }}(\mathrm{kW})$ & 22.89 & 24.5 & 7.0 \\
\hline$\eta_{\mathrm{II}}(\%)$ & 44.17 & 44.92 & 1.7 \\
\hline $\mathrm{M}_{\mathrm{co}}(\mathrm{kg} / \mathrm{s})$ & $2.07 \times 10^{-11}$ & $2.37 \times 10^{-11}$ & 14 \\
\hline $\mathrm{m}_{\mathrm{co} 2}(\mathrm{~kg} / \mathrm{s})$ & $4.85 \times 10^{-3}$ & $5.22 \times 10^{-3}$ & 7.6 \\
\hline $\mathrm{M}_{\mathrm{no}}(\mathrm{kg} / \mathrm{s})$ & $6.84 \times 10^{-6}$ & $6.91 \times 10^{-6}$ & 1.1 \\
\hline
\end{tabular}

\section{Investigation variations and obtaining optimum points using searching method}

Simulation results and various temperatures of cycle, for different ratio of air to fuel, for different modes of micro turbine are shown in figure $1-4$, are given in tables $3-6$ respectively.

Variations of first law efficiency according to ratio of air to fuel for four modes is shown in figure 13. As it is shown in this figure, for simple mode, efficiency of first law increases at first and at the point of ratio of air to fuel 1.7, reaches its peak. For CHP mode, optimum point is obtained at 1.6. Regarding these microturbines observe that until ratio of 1.6 to 1.7 , increasing generating power of micro gas turbine is superior to increasing work of air compressor and decreasing in mass flow of micro gas turbine because of decreasing temperature of combustion chamber; which leads to increasing efficiency. But in higher ratios than this optimum ratio, inverse is happened. Optimum point for cycle with regenerator exchanger, is obtained in ratio of air to fuel 1.3, and for CHP with regenerator cycle is obtained in ratio of 2.3. As it is observed, until ratio of 2.7, efficiency of first law of thermodynamic for CHP mode, is higher than CHPRG mode, and by increasing molar ratio of air to fuel, efficiency of CHPRG system will increase. The reason is that in general mode, with such increase, temperature of combustion chamber decreases and this decrease impress undesirable effects on regenerator heat exchanger performance, from other side, increasing air flow, increases performance of heat exchanger and consequently efficiency of the system increases. Sum of these two opposed effects, has led to formation of variations in first law efficiency based on figure 13. In CHPRG mode, with attention to preheating air flow before entering 
combustion chamber, this undesirable effect is neutralized as much as possible and with increasing molar ratio of air to fuel to more than 2.7, first law efficiency of this system increases.

Table 4. Simulation values for simple cycle of micro gas turbine with regenerator

\begin{tabular}{|c|c|c|c|c|c|c|c|c|}
\hline $\mathrm{r}_{\mathrm{a}}$ & $\dot{\mathrm{m}}_{\mathrm{f}}(\mathrm{kg} / \mathrm{s})$ & $\dot{\mathrm{m}}_{\mathrm{a}}(\mathrm{kg} / \mathrm{s})$ & $\mathrm{T}_{4}(\mathrm{~K})$ & $\mathrm{T}_{5}(\mathrm{~K})$ & $\dot{\mathrm{W}}_{\text {net }}(\mathrm{kW})$ & $\boldsymbol{\eta}_{t h} \mathbf{( \% )}$ & $\eta_{I I}(\%)$ & $F($ US\$/kWh $)$ \\
\hline 1 & 0.0019 & 0.03 & 3538.3 & 2292.5 & 32.02 & 33.61 & 72.83 & 0.0884 \\
\hline 2 & 0.0019 & 0.06 & 2170.6 & 1406.3 & 32.15 & 33.74 & 68.78 & 0.0881 \\
\hline 3 & 0.0019 & 0.09 & 1634.4 & 1059.0 & 30.28 & 31.78 & 61.94 & 0.0935 \\
\hline 4 & 0.0019 & 0.12 & 1355.6 & 878.3 & 28.13 & 29.52 & 55.88 & 0.1007 \\
\hline 5 & 0.0019 & 0.15 & 1184.4 & 767.7 & 25.86 & 27.14 & 50.31 & 0.1095 \\
\hline 6 & 0.0019 & 0.18 & 1069.5 & 692.9 & 23.54 & 24.70 & 45.07 & 0.1203 \\
\hline 7 & 0.0019 & 0.21 & 986.4 & 639.1 & 21.18 & 22.23 & 40.06 & 0.1337 \\
\hline 8 & 0.0019 & 0.24 & 923.6 & 598.4 & 18.80 & 19.73 & 35.21 & 0.1506 \\
\hline 9 & 0.0019 & 0.27 & 874.5 & 566.6 & 16.41 & 17.22 & 30.48 & 0.1726 \\
\hline 10 & 0.0019 & 0.30 & 835.1 & 541.1 & 14.00 & 14.70 & 25.84 & 0.2022 \\
\hline
\end{tabular}

Table 5. Simulation values for CHP cycle of micro gas turbine

\begin{tabular}{|c|c|c|c|c|c|c|c|c|}
\hline $\mathrm{r}_{\mathrm{a}}$ & $\dot{\mathrm{m}}_{\mathrm{f}}(\mathrm{kg} / \mathrm{s})$ & $\dot{\mathrm{m}}_{\mathrm{a}}(\mathrm{kg} / \mathrm{s})$ & $\mathrm{T}_{4}(\mathrm{~K})$ & $\mathrm{T}_{5}(\mathrm{~K})$ & $\dot{\mathrm{W}}_{\text {net }}(\mathrm{kW})$ & $\boldsymbol{\eta}_{t h}(\mathbf{O})$ & $\eta_{I I}(\%)$ & $F(U S \$ / k W h)$ \\
\hline 1 & 0.0019 & 0.03 & 2946.5 & 1909.1 & 25.34 & 43.8 & 56.04 & 0.0679 \\
\hline 2 & 0.0019 & 0.06 & 1943.1 & 1259.0 & 27.17 & 34.78 & 58.21 & 0.0855 \\
\hline 3 & 0.0019 & 0.09 & 1505.5 & 975.4 & 26.09 & 30.48 & 53.25 & 0.0975 \\
\hline 4 & 0.0019 & 0.12 & 1273.4 & 825.1 & 24.58 & 27.65 & 48.41 & 0.1075 \\
\hline 5 & 0.0019 & 0.15 & 1130.0 & 732.1 & 22.91 & 25.85 & 43.86 & 0.1149 \\
\hline 6 & 0.0019 & 0.18 & 1032.5 & 699.0 & 21.16 & 24.06 & 39.56 & 0.1235 \\
\hline 7 & 0.0019 & 0.21 & 962.0 & 623.3 & 19.35 & 22.21 & 35.47 & 0.1338 \\
\hline 8 & 0.0019 & 0.24 & 908.7 & 588.7 & 17.52 & 20.33 & 31.55 & 0.1461 \\
\hline 9 & 0.0019 & 0.27 & 866.9 & 561.7 & 15.67 & 18.43 & 27.77 & 0.1612 \\
\hline 10 & 0.0019 & 0.30 & 833.2 & 539.9 & 13.80 & 16.51 & 24.11 & 0.1800 \\
\hline
\end{tabular}

Table 6. Simulation values for CHP cycle of micro gas turbine with regeneration (CHPRG)

\begin{tabular}{|c|c|c|c|c|c|c|c|c|}
\hline $\mathrm{r}_{\mathrm{a}}$ & $\dot{\mathrm{m}}_{\mathrm{f}}(\mathrm{kg} / \mathrm{s})$ & $\dot{\mathrm{m}}_{\mathrm{a}}(\mathrm{kg} / \mathrm{s})$ & $\mathrm{T}_{4}(\mathrm{~K})$ & $\mathrm{T}_{5}(\mathrm{~K})$ & $\dot{\mathrm{W}}_{\text {net }}(\mathrm{kW})$ & $\boldsymbol{\eta}_{\text {th }}(\mathbf{\%})$ & $\eta_{I I}(\%)$ & $F($ US\$/kWh $)$ \\
\hline 1 & 0.0019 & 0.03 & 3538.3 & 2292.5 & 32.02 & 51.09 & 72.83 & 0.0582 \\
\hline 2 & 0.0019 & 0.06 & 2170.6 & 1406.3 & 32.15 & 39.90 & 68.78 & 0.0745 \\
\hline 3 & 0.0019 & 0.09 & 1634.4 & 1059.0 & 30.28 & 34.83 & 61.94 & 0.0853 \\
\hline 4 & 0.0019 & 0.12 & 1355.6 & 878.3 & 28.13 & 31.35 & 55.88 & 0.0948 \\
\hline 5 & 0.0019 & 0.15 & 1184.8 & 767.7 & 25.86 & 28.94 & 50.31 & 0.1027 \\
\hline 6 & 0.0019 & 0.18 & 1069.5 & 692.9 & 23.54 & 26.56 & 45.07 & 0.1119 \\
\hline 7 & 0.0019 & 0.21 & 986.4 & 639.1 & 21.20 & 24.15 & 40.06 & 0.1231 \\
\hline 8 & 0.0019 & 0.24 & 923.6 & 598.4 & 18.81 & 21.71 & 35.21 & 0.1369 \\
\hline 9 & 0.0019 & 0.27 & 874.5 & 566.6 & 16.41 & 19.25 & 30.48 & 0.1544 \\
\hline 10 & 0.0019 & 0.30 & 835.1 & 541.1 & 14.00 & 16.78 & 25.84 & 0.1771 \\
\hline
\end{tabular}




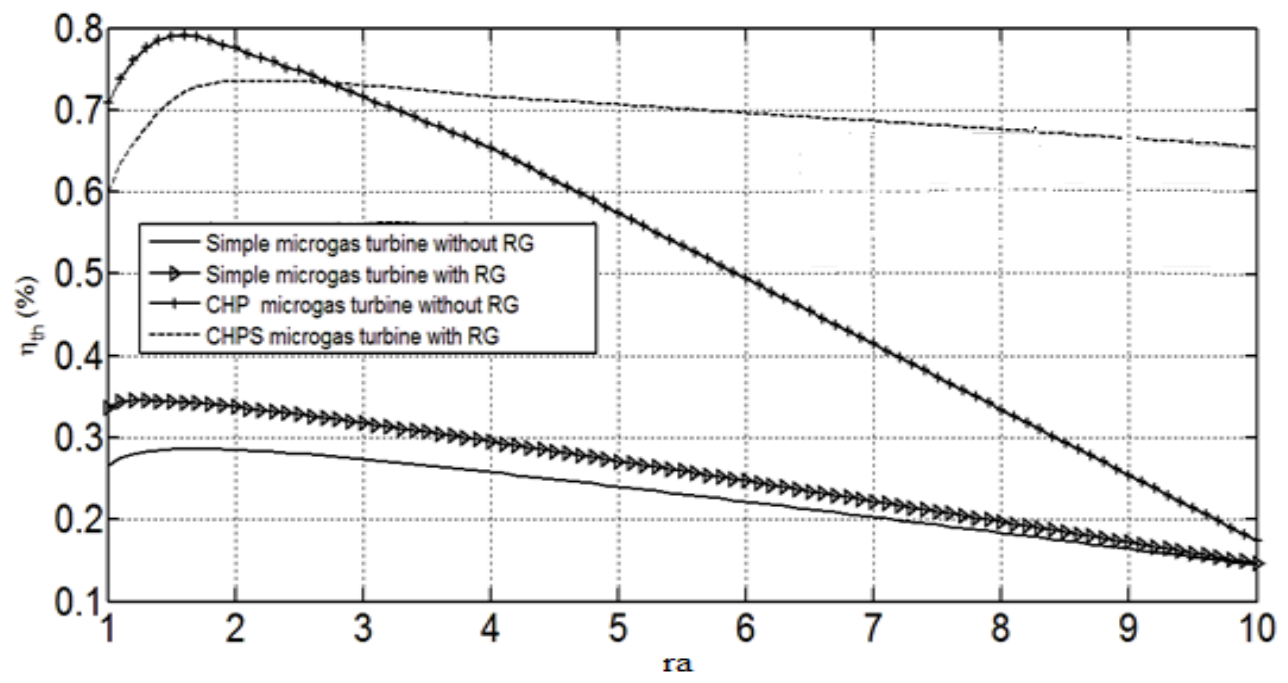

Figure 13. Variations of first law efficiency based on molar ratio of air to fuel for four modes

Variations in second law efficiency based on molar ratio of air to fuel is shown in figure 14. As it is shown in the figure, for simple, RG, CHP and CHPRG modes, optimum points are 1.4, 1.1, 1.3 and 2.6. With increasing molar ratio of air to fuel, temperature of exhaust will decrease, and from other hand output mass flow of microturbine increases. Furthermore, with increasing molar ratio of air to fuel, input exergy of air increases which causes increasing efficiency. Sum of above effects also effect of variations in output power of microturbine with ratio of air to fuel, is as figure 14 which shows effect of molar ratio of air to fuel on efficiency of second thermodynamic law.

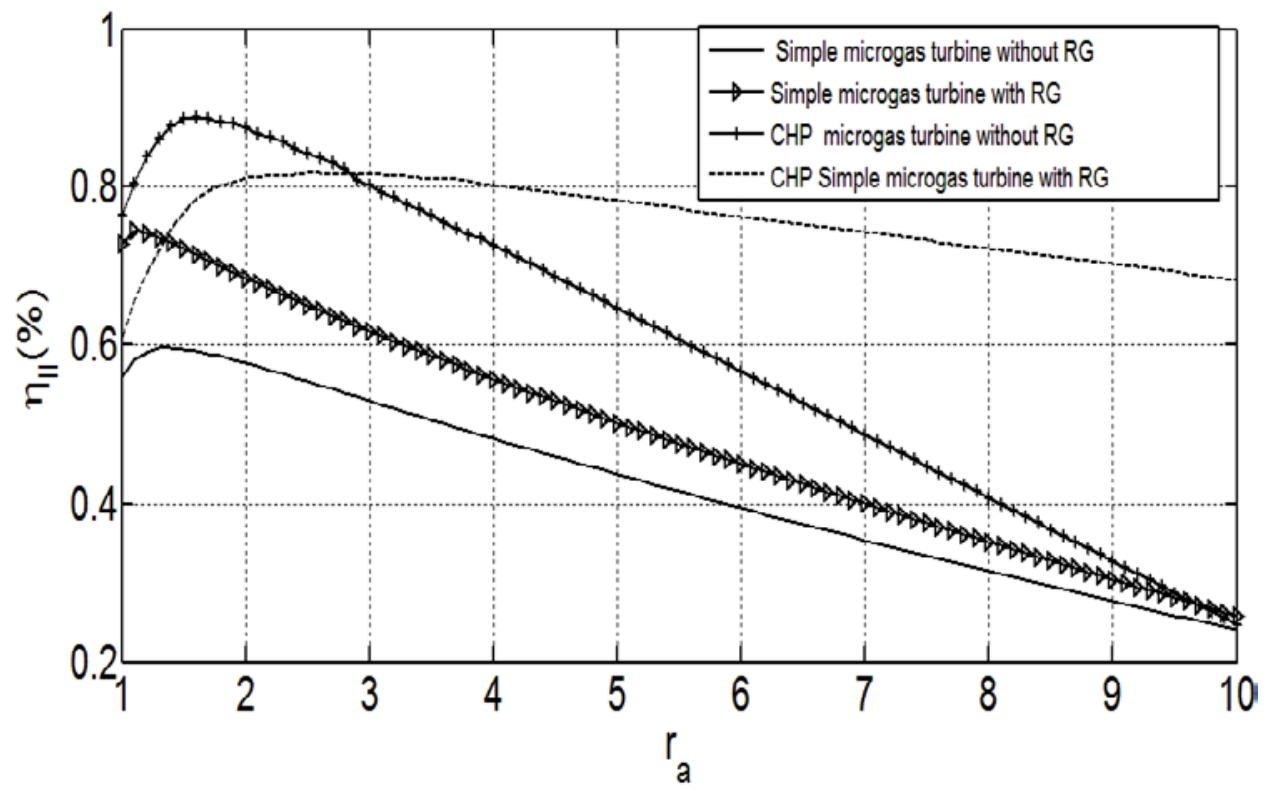

Figure 14. Variations of second law efficiency based on molar ratio of air to fuel for four modes

Variations of cost function based on ratio of air to fuel are shown in figure 15. As shown, optimal points for simple, RG, CHP and CHPRG modes are 1.7, 1.3, 1.1 and 1.3. Diagrams show that cost function has minimum value for CHP cycle and CHPRG cycle has highest cost for generating electricity. 


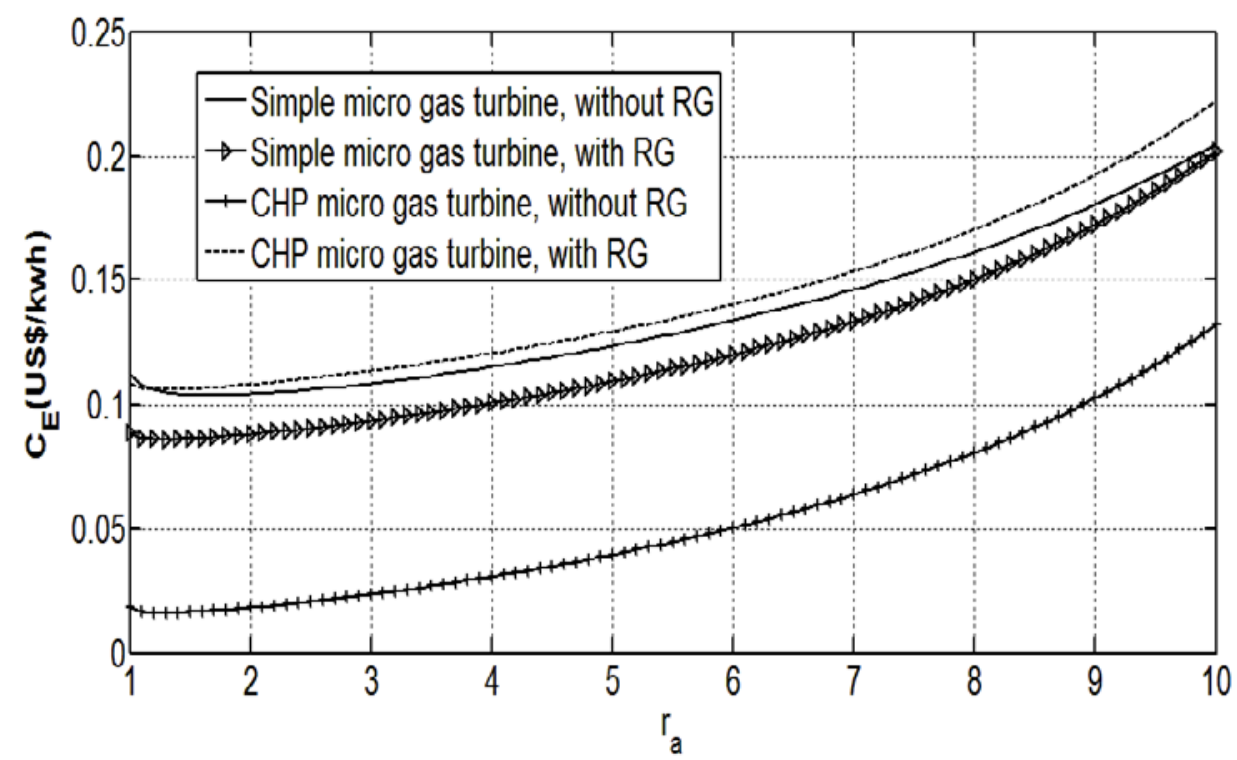

Figure 15. Variations of cost function based on molar ratio of air to fuel for four modes

Variations of generating entropy for simple, RG, CHP and CHPRG modes of microturbine based on molar ratio of air to fuel are shown in figure 16. With attention to this figure, we found that optimal values in figure 13 which shows peak of first thermodynamic law efficiency, coincide with minimum generating entropy.

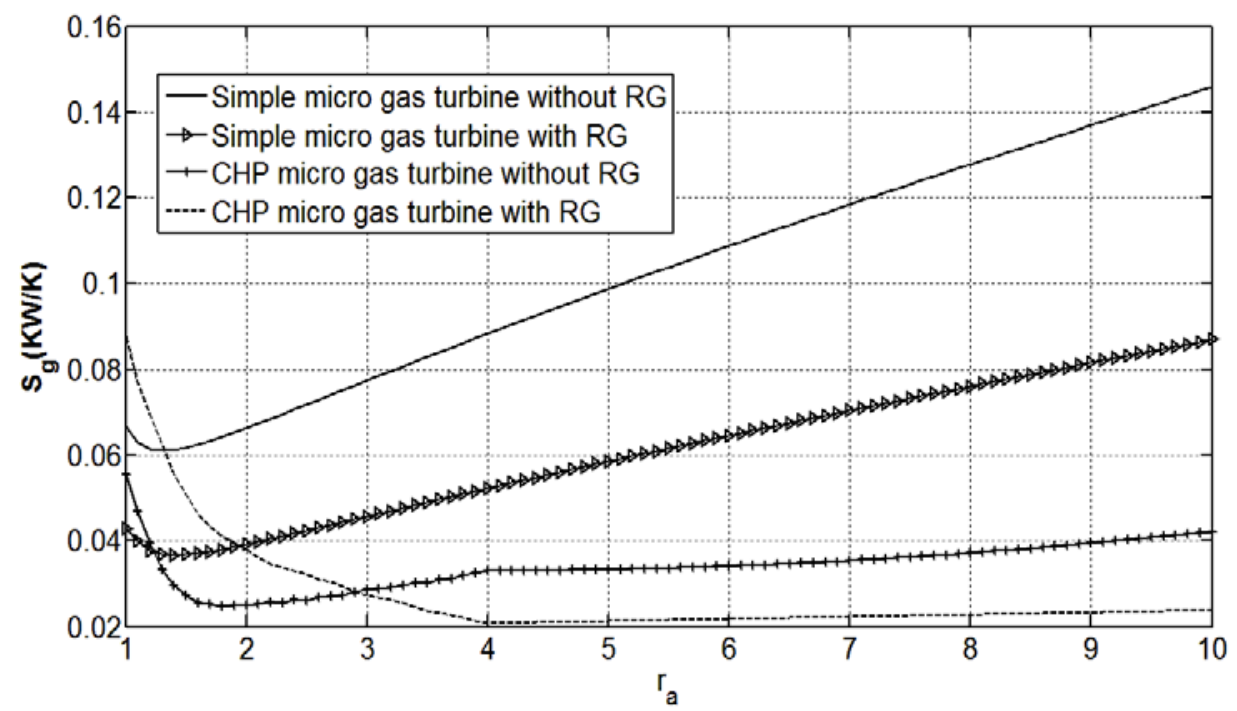

Figure 16. Variations of generating entropy based on molar ratio of air to fuel for four modes

\section{Optimization by Genetic algorithm}

In Genetic algorithm, problem is evaluated with a completely random primary population considering objective function. A search procedure is started and by combination of selection factors, connection and mutation from local extremum points, is used to find best solution. In this study, we aim to maximize energy and exergy efficiency and minimize cost and generating entropy. Objective function is evaluated for each mode and optimal points are determined. Population size is 300 . Selection mechanism as Tournament method is used to generate generation and also connection performance and mutation with probability of 0.9 and 0.02 are considered. Four parameters as input of objective function and actually four genes forming each chromosome are ratio of air to fuel, pressure ratio, turbine efficiency and compressor efficiency. Variations confine of these parameters is shown in table 7 and other parameters are constant. In order to solve optimization problem, objective function is calculated by using written code and optimization is done by summon Genetic algorithm toolbox in Matlab. Objective function in all parts is considered as four aiming to minimize generating entropy $\left(\dot{\mathrm{S}}_{\text {gen }}\right)$ and cost function 
(CE), and maximize energy and exergy efficiency which is considered here as minimizing functions $1-\eta_{\text {th }}$ and 1$\eta_{\text {II. }}$

Table 7. Variations confine of parameters in Genetic algorithm

\begin{tabular}{|c|c|c|}
\hline High limit & Low limit & Parameter \\
\hline 10 & 1 & Ratio of air to fuel: $\mathrm{r}_{\mathrm{a}}$ \\
\hline 6.5 & 4 & Pressure ratio: $\mathrm{r}_{\mathrm{c}}$ \\
\hline 0.85 & 0.5 & Efficiency of turbine: $\eta_{t}$ \\
\hline 0.85 & 0.5 & Efficiency of compressor; $\eta_{c}$ \\
\hline
\end{tabular}

Convergence diagram for optimizing four modes of micro gas turbine by genetic algorithm is shown in figures 17 to 20 .

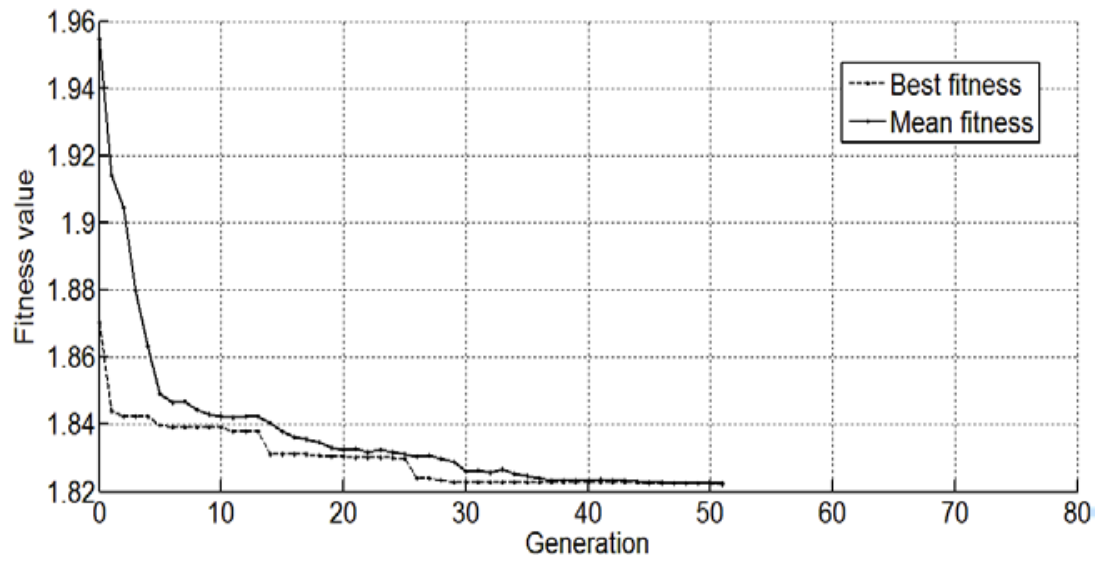

Figure 17. Convergence diagram for optimizing simple cycle of micro gas turbine by genetic algorithm

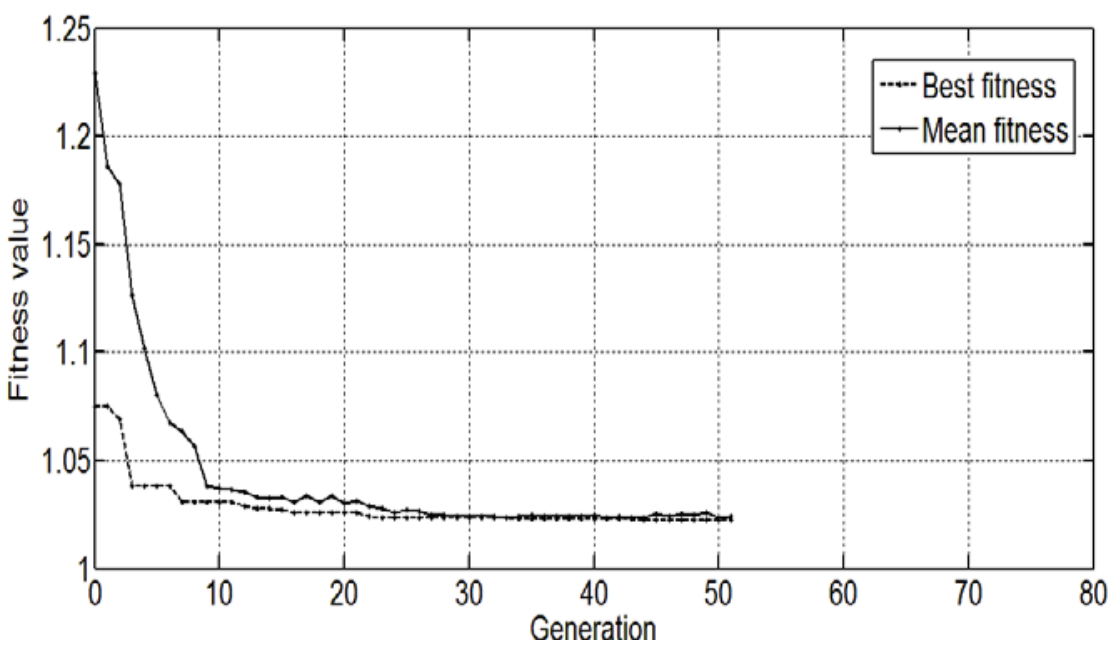

Figure 18. Convergence diagram for optimizing RG cycle of micro gas turbine by genetic algorithm 


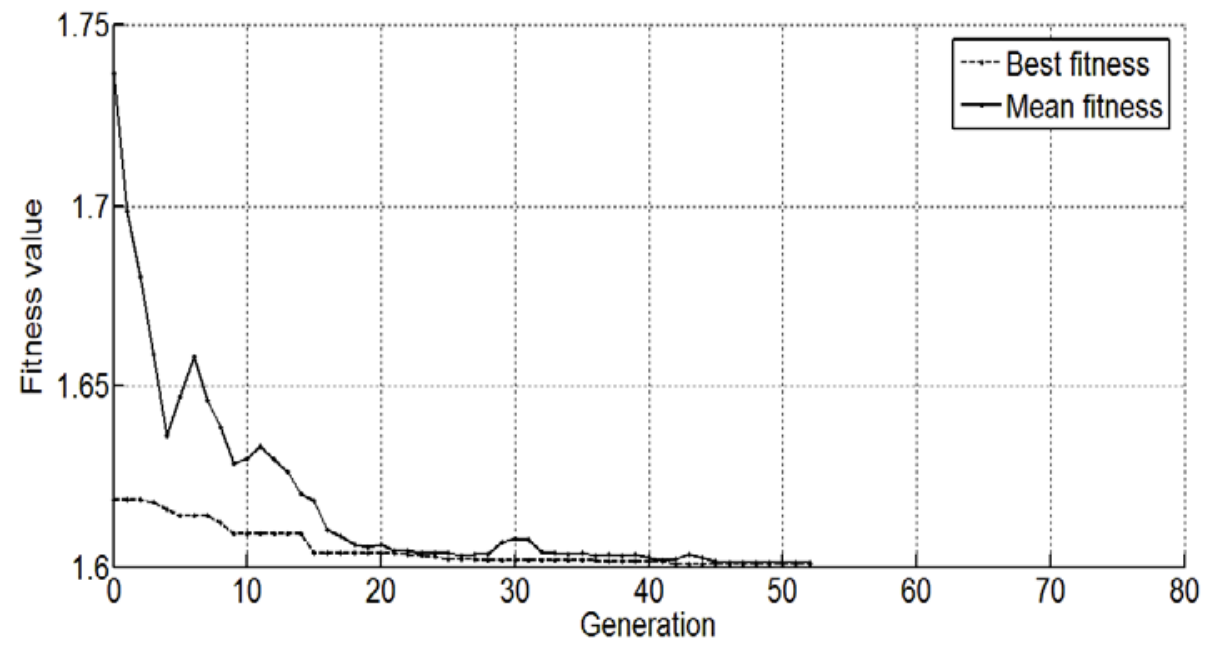

Figure 19. Convergence diagram for optimizing CHP cycle of micro gas turbine by genetic algorithm

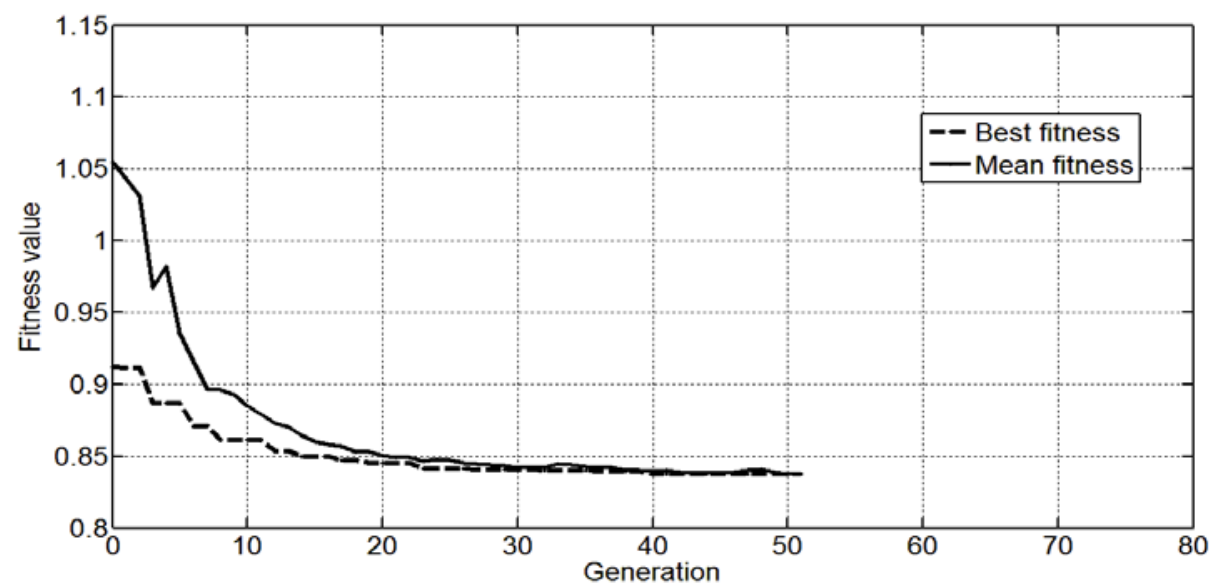

Figure 20. Convergence diagram for optimizing CHPRG cycle of micro gas turbine by genetic algorithm

Results of optimal mode and values of energy efficiency, exergy efficiency, cost function and generating entropy at these points by Genetic algorithm are given in table 8 .

Table 8. Results of optimal mode by Genetic algorithm

\begin{tabular}{|c|l|c|c|c|c|c|c|c|}
\hline Cycle mode & $\mathrm{ra}_{\mathrm{a}}$ & $\mathrm{r}_{\mathrm{c}}$ & $\eta_{t}(\%)$ & $\eta_{c}(\%)$ & $\eta_{\text {th }}(\%)$ & $\eta_{\text {II }}(\%)$ & Sgen $(\mathrm{kW} / \mathrm{K})$ & CE(US\$ $/ \mathrm{kWh})$ \\
\hline Simple mode & 1.40 & 6.4 & 87 & 80 & 29.01 & 61.38 & 0.0583 & 0.1024 \\
& & & & & & & & \\
\hline RG mode & 1.21 & 6.5 & 80 & 85 & 34.39 & 74.86 & 0.0369 & 0.0864 \\
\hline CHP mode & 1.42 & 6.5 & 81 & 84 & 39.42 & 85.42 & 0.0529 & 0.0754 \\
\hline CHPRG mode & 1.82 & 6.5 & 85 & 82 & 38.22 & 57.25 & 0.0652 & 0.0286 \\
\hline
\end{tabular}

\section{Optimization by Bee colony algorithm}

In order to optimize by Bee colony algorithm, first several parameters should be considered as input parameters which include ratio of air to fuel, pressure ratio, turbine efficiency and compressor efficiency. Number of cycles obtained for optimization and convergence is equal to 300. Number of primary bees in each generation is equal to 100 which $50 \%$ is considered as employee bees in every step. Number of iterations to reach convergence is considered as 50. Other parameters of bee colony and their changes are considered as Genetic algorithm. Convergence diagram for optimization of four modes of micro gas turbine by Bee colony algorithm is shown in figure 21 to 24 . 


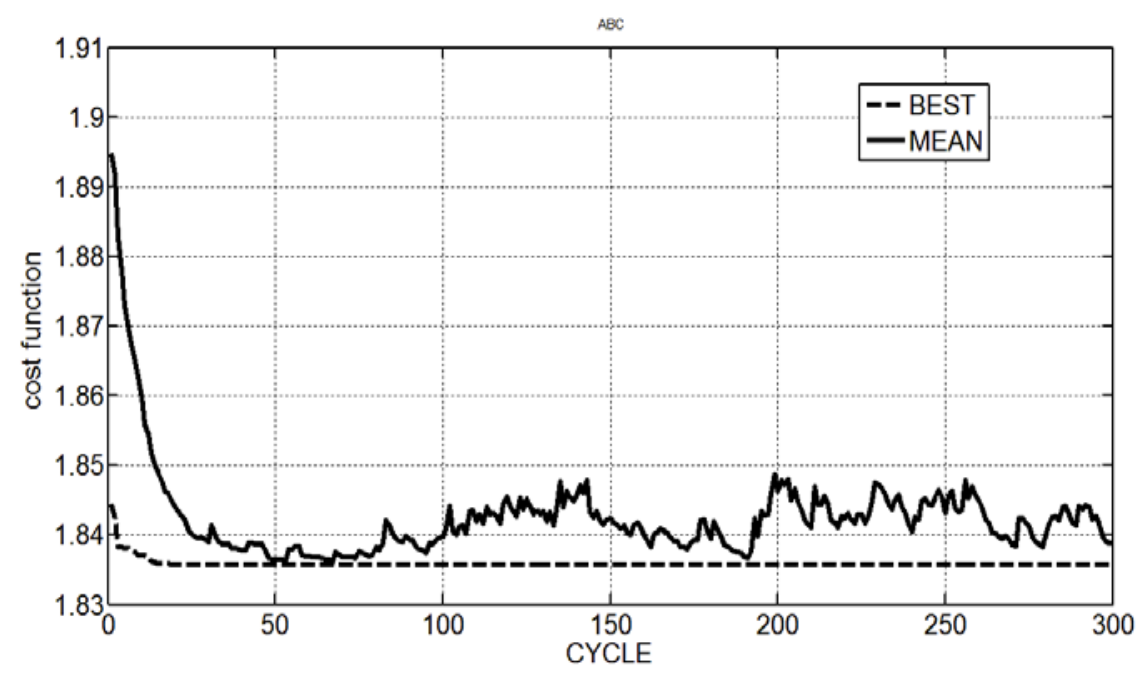

Figure 21. Convergence diagram for optimization of simple cycle of micro gas turbine by Bee colony algorithm

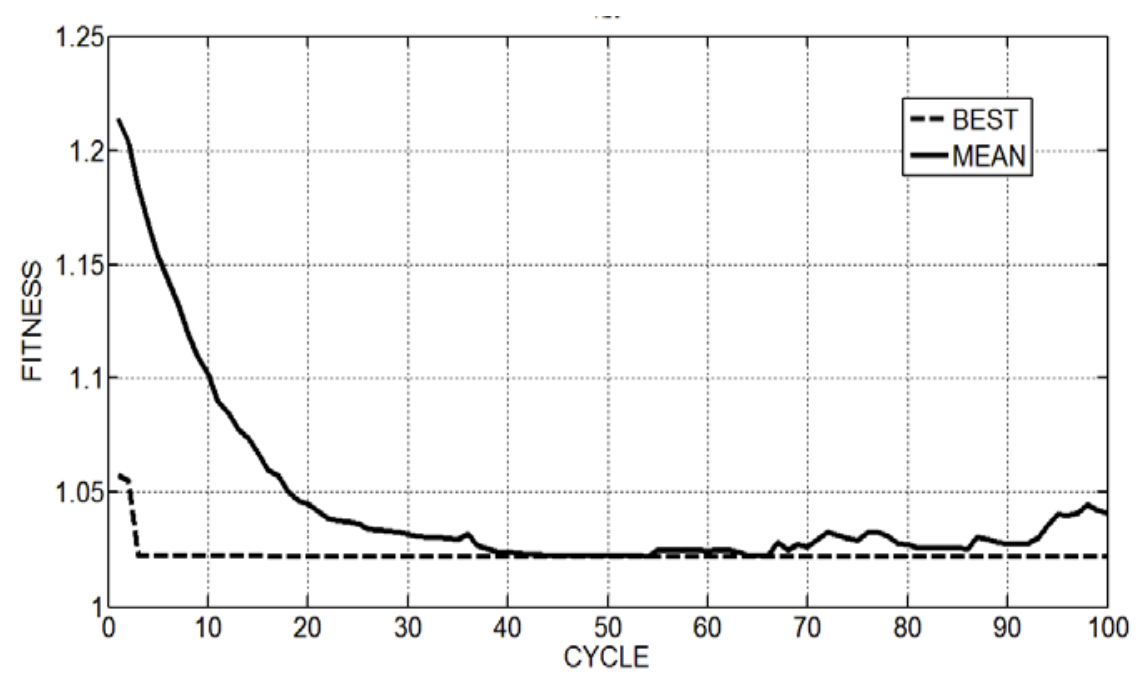

Figure 22. Convergence diagram for optimization of RG cycle of micro gas turbine by Bee colony algorithm

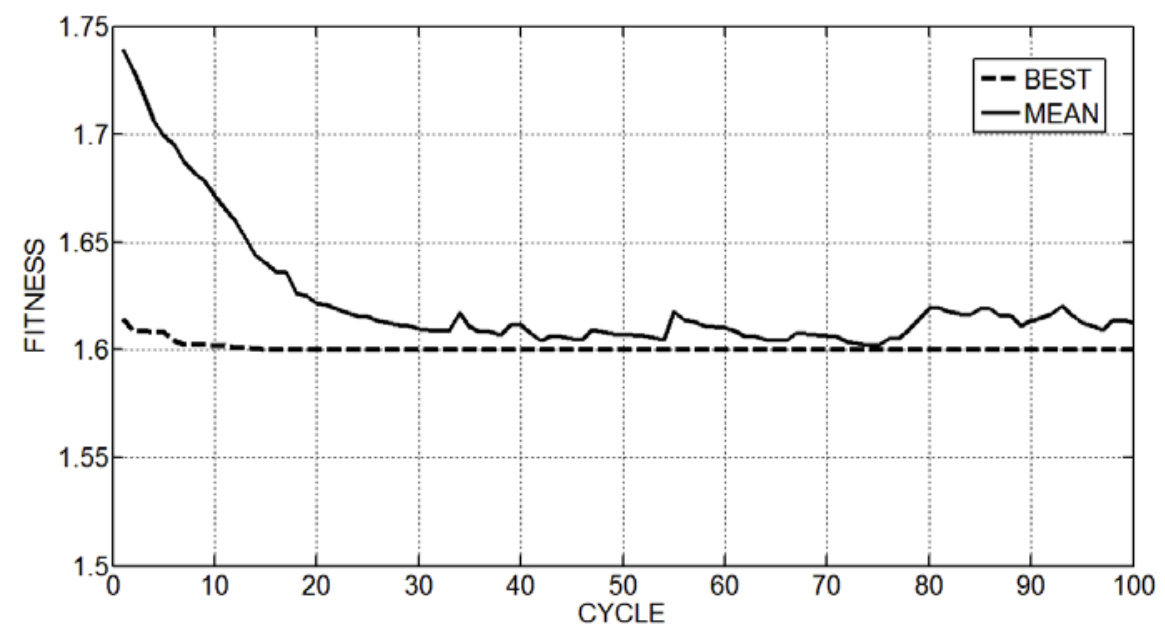

Figure 23. Convergence diagram for optimization of CHP cycle of micro gas turbine by Bee colony algorithm 


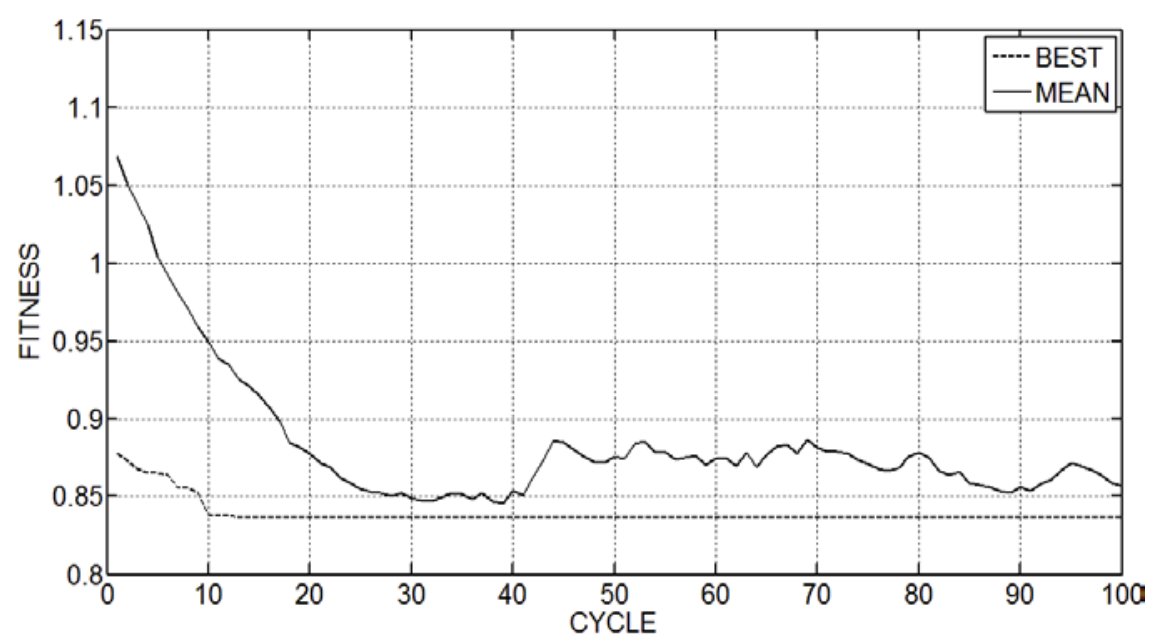

Figure 24. Convergence diagram for optimization of CHPRG cycle of micro gas turbine by Bee colony algorithm

Results of optimal mode and values of energy efficiency, exergy efficiency, cost function and generating entropy at these points by Bee colony algorithm are given in table 9 .

Table 9. Results of optimal mode by Bee colony algorithm

\begin{tabular}{|c|c|c|c|c|c|c|c|c|}
\hline Cycle mode & $\mathrm{ra}_{\mathrm{a}}$ & $\mathrm{r}_{\mathrm{c}}$ & $\eta_{t}(\%)$ & $\eta_{c}(\%)$ & $\eta_{\text {th }}(\%)$ & $\eta_{I I}(\%)$ & $\dot{\mathrm{S}}_{\text {gen }}(\mathrm{kW} / \mathrm{K})$ & $\mathrm{CE}(\mathrm{US} \$ / \mathrm{kWh})$ \\
\hline Simple mode & 1.36 & 6.5 & 85 & 80 & 28.25 & 60.96 & 0.0578 & 0.1052 \\
\hline RG mode & 1.13 & 6.5 & 80 & 85 & 34.30 & 75.67 & 0.0352 & 0.0866 \\
\hline CHP mode & 1.32 & 6.5 & 80 & 85 & 40.53 & 81.8 & 0.0578 & 0.0733 \\
\hline CHPRG mode & 1.61 & 6.5 & 85 & 85 & 35.6 & 56.65 & 0.0745 & 0.0297 \\
\hline
\end{tabular}

In order to compare optimization methods, first we should note that Searching algorithm only gives a general guess about optimal points at points where we simulated the problem and is not reliable. This method is applicable when we have a general interval of performance parameters of the system, and want to determine optimal points in this interval. In order to compare Genetic algorithm and Bee colony algorithm, it should be mentioned that results of these two methods are very close, but Genetic algorithm has the advantage of getting solution faster.

\section{CONCLUSION}

In this study, first micro gas turbine cycle is modelled in four modes: simple, with regeneration exchanger, combined generation of heat and power and combined generation of heat and power with regeneration exchanger modes. Then obtained results are validated by using results of other literatures. Next, by keeping all parameters constant, change of energy efficiency, second law efficiency and cost function are investigated by considering environmental factors. Finally, Genetic algorithm and Bee colony algorithm are used to obtain optimal performance points. In this part, investigated parameters were ratio of air to fuel, pressure ratio, turbine efficiency and compressor efficiency and using two methods, results are obtained for optimal modes of energy efficiency, second law efficiency and cost function. In general mode, considering maximum values for energy and exergy and minimum value for cost function, optimal points of ratio of air to fuel for simple cycle, RG cycle, CHP cycle and CHPRG cycle are obtained as 1.6, 1.25, 1.3 and 1.6, respectively. With attention to temperature limitations due to metallurgical limitations of turbine blades which limit input temperature of turbine to lower than $1100 \mathrm{~K}$, optimal point in simple mode and CHP mode are obtained at ratio of 5.31 and efficiency of cycles at this point are 0.235 and 0.352 . Also for CHP and CHPRG cycles optimal point are obtained at ratio of air to fuel 5.73 and efficiency of cycles at this point are 0.253 and 0.634 . Finally we can refer to this fact as one of the most important results of the study that by increasing thermal resistance of blades in micro gas turbines, in simple mode by 
reaching input temperature of $2246 \mathrm{~K}$, efficiency increases by $21 \%$, in RG cycle, by reaching input temperature to $3062 \mathrm{~K}$, efficiency increases by $36 \%$, in CHP cycle, by reaching input temperature to $2564 \mathrm{~K}$, efficiency increases by $15 \%$ and in CHPRG cycle, by reaching input temperature to $2840 \mathrm{~K}$, efficiency increases by $30 \%$ proportional to a cycle with temperature limitations.

\section{Nomenclature}

$\mathrm{C}_{\mathrm{E}} \quad$ Electricity cost (US\$/kWh)

e Exergy $(\mathrm{kJ} / \mathrm{kg})$

EEave Average of consumed electricity $(k W h /$ day)

$\mathrm{H} \quad$ Enthalpy $(\mathrm{kJ} / \mathrm{kg})$

$\mathrm{h}_{0} \quad$ Enthalpy in reference temperature $(\mathrm{kJ} / \mathrm{kg})$

$\mathrm{h}_{\mathrm{f}}{ }_{\mathrm{f}} \quad$ Enthalpy of formation $(\mathrm{kJ} / \mathrm{kg})$

h Convection heat transfer coefficient $\left(W / m^{2} K\right)$

K Ratio of $\mathrm{C}_{\mathrm{p}}$ to $\mathrm{C}_{\mathrm{v}}$

LHV Low thermal value of fuel $(\mathrm{kJ} / \mathrm{kg})$

$\dot{\mathrm{m}} \quad$ Mass flow rate $(\mathrm{kg} / \mathrm{s})$

NTU Number of thermal units

$\mathrm{Nu} \quad$ Nusselt number

$\mathrm{P} \quad$ Pressure $(\mathrm{kPa})$

$\mathrm{R} \quad$ Gas constant $(\mathrm{kJ} / \mathrm{kgK})$

Re Reynolds number

$r_{a} \quad$ Air fuel ratio

$r_{c} \quad$ Compressor pressure ratio

Rt Gas turbine pressure ratio

Re Reynolds number

$\dot{\mathrm{S}}_{\mathrm{g}} \quad$ Entropy generation $(\mathrm{kW} / \mathrm{K})$

$\mathrm{T}$ Temperature (K)

$\mathrm{u}_{\max } \quad$ Maximum speed of the gas $(\mathrm{m} / \mathrm{s})$

$\mathrm{u}_{\infty} \quad$ Free flow speed of the gas $(\mathrm{m} / \mathrm{s})$

W Work per mass flow rate $(\mathrm{kJ} / \mathrm{kg})$

$\dot{\mathrm{W}}_{\text {net }} \quad$ Net power generation $(\mathrm{kW})$

\section{Greek symbols}

$\begin{array}{ll}\varepsilon & \text { Effectiveness } \\ \eta & \text { Efficiency } \\ \mu & \text { Viscosity coefficient of water }(N . S / m) \\ \rho & \text { Density }\left(\mathrm{kg} / \mathrm{m}^{3}\right) \\ \text { Subscript } & \text { Air } \\ \text { A } & \text { Booster compressor } \\ \text { BC } & \text { Compressor } \\ \text { C } & \text { Combustion chamber } \\ \text { CC } & \text { Chemical } \\ \text { Ch } & \text { Fuel } \\ \text { F } & \text { Gas } \\ \text { G } & \text { First law } \\ \text { I } & \text { Second law } \\ \text { II } & \text { Physical } \\ \text { ph } & \text { Total } \\ \text { T } & \end{array}$




\section{REFERENCES}

[1] Aliehyaei M, Atabi F, Khorshidvand M, Rosen MA. Exergy, economic and environmental analysis for simple and combined heat and power IC engines. Sustainability. 2015;7:4411-24 DOI:10.3390/su7044411

[2] Ashari G, Ehyaei M, Mozafari A, Atabi F, Hajidavalloo E, Shalbaf S. Exergy, economic, and environmental analysis of a PEM fuel cell power system to meet electrical and thermal energy needs of residential buildings. Jour of Fuel Cell Sci and Tech. 2012;9:051001 DOI: 10.1115/1.4006049.

[3] Ehyaei M, Ahmadi P, Atabi F, Heibati M, Khorshidvand M. Feasibility study of applying internal combustion engines in residential buildings by exergy, economic and environmental analysis. Energy Build. 2012;55:405-13 DOI:10.1016/j.enbuild.2012.09.002.

[4] Ehyaei M, Bahadori M. Selection of micro turbines to meet electrical and thermal energy needs of residential buildings in Iran. Energy Build. 2007;39:1227-34 DOI:10.016/j.enbuild.2007.01.006.

[5] Ehyaei M, Hakimzadeh S, Enadi N, Ahmadi P. Exergy, economic and environment (3E) analysis of absorption chiller inlet air cooler used in gas turbine power plants. Int J of Energy Res. 2012;36:486-98 DOI:/10.1002/er.814.

[6] Ehyaei M, Mozafari A, Ahmadi A, Esmaili P, Shayesteh M, Sarkhosh M, et al. Potential use of cold thermal energy storage systems for better efficiency and cost effectiveness. Energy Build. 2010;42:2296-303 DOI:10.1016/j.enbuild.2010.07.013.

[7] Ehyaei M, Mozafari A, Alibiglou M. Exergy, economic \& environmental (3E) analysis of inlet fogging for gas turbine power plant. Energy. 2011;36:6851-61 DOI: 10.1016/j.energy.2011.10.011.

[8] Ehyaei MA, Tahani M, Ahmadi P, Esfandiari M. Optimization of fog inlet air cooling system for combined cycle power plants using genetic algorithm. Appl Ther Eng. 2015;76:449-61 10.1016/j.applthermaleng.2014.11.032.

[9] Mohammadnezami MH, Ehyaei MA, Rosen MA, Ahmadi MH. Meeting the electrical energy needs of a residential building with a wind-photovoltaic hybrid system. Sustainability. 2015;7:2554-69 DOI:10.3390/su7032554.

[10] Mozafari A, Ahmadi A, Ehyaei M. Optimisation of micro gas turbine by exergy, economic and environmental (3E) analysis. IntJ Exergy. 2010;7:1 DOI:10.1504/IJEX.2010.029611.

[11] Saidi M, Abbassi A, Ehyaei M. Exergetic optimization of a PEM fuel cell for domestic hot water heater. Journal Fuel Cell Sci and Tech. 2005;2:284-9 DOI: 10.1115/1.2041672.

[12] Saidi M, Ehyaei M, Abbasi A. Optimization of a combined heat and power PEFC by exergy analysis. J Power Sources. 2005;143:179-84 DOI:10.1016/j.jpowsour.2004.11.061.

[13] Shamoushaki M, Ehyaei M, Ghanatir F. Exergy, economic and environmental analysis and multi-objective optimization of a SOFC-GT power plant. Energy. 2017;134:515-31 DOI:10.1016/j.energy.2017.06.058.

[14] Yazdi BA, Yazdi BA, Ehyaei MA, Ahmadi A. Optimization of micro combined heat and power gas turbine by genetic algorithm. Ther Sci. 2015;19:207-18 DOI:10.2298/TSCI121218141.

[15] Ponce-Ortega JM, Serna-González M, Jiménez-Gutiérrez A. Use of genetic algorithms for the optimal design of shell-and-tube heat exchangers. Appl Ther Eng. 2009;29:203-9 DOI:/10.1016/j.applthermaleng.2007.06.040.

[16] Ravagnani MASS, Caballero JA. Optimal heat exchanger network synthesis with the detailed heat transfer equipment design. Comp \& Ch Eng. 2007;31:1432-48 DOI:10.016/j.compchemeng.2006.12.005.

[17] Mozafari A, Ehyaei M. Effects of regeneration heat exchanger on entropy, electricity cost, and environmental pollution produced by micro gas turbine system. IntJ green energy. 2012;9:51-70 DOI:10.1080/15435075.2011.617021.

[18] Shamoushaki M, EHYAEI MA. EXERGY, ECONOMIC, AND ENVIRONMENTAL (3E) ANALYSIS OF A GAS TURBINE POWER PLANT AND OPTIMIZATION BY MOPSO ALGORITHM. Therl Sci. 2018;22:2641-51 DOI:10.298/TSCI161011091S.

[19] Shamoushaki M, Ghanatir F, Ehyaei M, Ahmadi A. Exergy and exergoeconomic analysis and multiobjective optimisation of gas turbine power plant by evolutionary algorithms. Case study: Aliabad Katoul power plant. Int J Exergy. 2017;22:279-307 DOI:10.1504/IJEX.2017.083160.

[20] Labinov S, Zaltash A, Rizy DT, Fairchild PD, DeVault R, Vineyard E. Predictive algorithms for microturbine performance for BCHP systems. ASHRAE Trans. 2002;108:670-81 DOI:10.1.1.488.301.

[21] Ahmadi A, Ehyaei M. Exergy analysis of a wind turbine. Int J Exergy. 2009;6:457-76 DOI:10.1504/IJEX.2009.026672.

[22] Ali Ehyaei M, Tanehkar M, Rosen MA. Analysis of an Internal Combustion Engine Using Porous Foams for Thermal Energy Recovery. Sustainability. 2016;8:267 DOI:10.3390/su8030267.

[23] Asgari E, Ehyaei M. Exergy analysis and optimisation of a wind turbine using genetic and searching algorithms. Int J Exergy. 2015;16:293-314 DOI:10.1504/IJEX.2015.068228. 
[24] Chegini S, Ehyaei M. Economic, exergy, and the environmental analysis of the use of internal combustion engines in parallel-to-network mode for office buildings. J Brazilian Soc of Mech Sci and Eng. 2018;40:433 DOI:10.1007/s40430-018-1349-4.

[25] Darvish K, Ehyaei MA, Atabi F, Rosen MA. Selection of optimum working fluid for Organic Rankine Cycles by exergy and exergy-economic analyses. Sustainability. 2015;7:15362-83 DOI:10.3390/su71115362.

[26] Ehyaei M, Bahadori M. Internalizing the social cost of noise pollution in the cost analysis of electricity generated by wind turbines. Wind Eng. 2006;30:521-9 DOI: 10.1260/030952406779994114.

[27] Ehyaei M, Rosen MA. Optimization of a triple cycle based on a solid oxide fuel cell and gas and steam cycles with a multiobjective genetic algorithm and energy, exergy and economic analyses. Energy Con and Manag. 2019;180:689-708 DOI:10.1016/j.enconman.2018.11.023.

[28] Ehyaei MA. Estimation of condensate mass flow rate during purging time in heat recovery steam generator of combined cycle power plant. Ther Sci. 2014;18:1389-97 DOI:10.2298/tsci111031102e.

[29] Ghasemian E, Ehyaei M. Evaluation and optimization of organic Rankine cycle (ORC) with algorithms NSGA-II, MOPSO, and MOEA for eight coolant fluids. Int J of Energy and Environ Eng. 2018;9:39-57 10.1007/s40095-017-0251-7.

[30] Hamid Kazemi MAE. Energy, exergy, and economic analysis of a geothermal power plant. adv geo-energy research. 2018;2:190-209 DOI:10.26804/ager.2018.02.07.

[31] Yousefi M, Ehyaei M. Feasibility study of using organic Rankine and reciprocating engine systems for supplying demand loads of a residential building. Adv in Build Ener Rese. 2017:1-17 DOI:0.1080/17512549.2017.1354779.

[32] Kaikko J, Backman J. Technical and economic performance analysis for a microturbine in combined heat and power generation. Energy. 2007;32:378-87 DOI:10.1016/j.energy.2006.06.013

[33] Haugwitz S. Modelling of microturbine systems. 2003 European Control Conference (ECC): IEEE; 2003. p. 1234-9

[34] Bergman TL, Incropera FP, Lavine AS, Dewitt DP. Introduction to heat transfer: John Wiley \& Sons; 2011.

[35] Bejan A. Fundamentals of exergy analysis, entropy generation minimization, and the generation of flow architecture. Int J Energy Res. 2002;26: 0-43 DOI:10.1002/er.804.

[36] Frangopoulos CA. Thermo-economic functional analysis and optimization. Energy. 1987;12:563-71 10.1016/0360-5442(87)90097-1.

[37] Horngren CT, Foster G, Datar SM. Cost Accounting: A Managerial Emphasis, Prentice Hall. Inc; 2003.

[38] Glover F. Future paths for integer programming and links to artificial intelligence. Comp \& oper resea. 1986;13:533-49 DOI: /10.1016/0305-548(86)90048-1.

[39] Rohaninejad M, Kheirkhah AS, Vahedi Nouri B, Fattahi P. Two hybrid tabu search-firefly algorithms for the capacitated job shop scheduling problem with sequence-dependent setup cost. Int JComputer Integ Manuf. 2015;28:470-87 DOI:10.1080/0951192X.2014.880808.

[40] Karaboga D, Basturk B. A powerful and efficient algorithm for numerical function optimization: artificial bee colony (ABC) algorithm. J glob optim. 2007;39:459-71 DOI:10.1007/s10898-007-9149-x. 